\title{
İdari Coğrafya ve Yerleşme Coğrafyası Açısından Mahalle Kavramı
}

\section{The Notion of Neighborhood in Terms of Administrative Geography and Settlement Geography}

\section{Okan TÜRKAN ${ }^{1}$ (])}

${ }^{1}$ Dr. Öğretim Üyesi, Çankırı Karatekin Üniversitesi, Edebiyat Fakültesi, Coğrafya Bölümü, Çankırı, Türkiye

ORCID: O.T. 0000-0002-5575-0322

\section{öz}

Türkiye'de mahalle kavramının yerleşme ve yönetsel coğrafyada farklı karşılıkları bulunmaktadır. Aynı isme ve farklı bağlamlara sahip olan mahallenin çoklu görünümü bazı karışıklıklar meydana getirmektedir. Bu çalışma mahalleyle ilgili ortaya çıkan karışıklıkların sebeplerini hem yerleşme coğrafyası hem de yönetsel yapı itibarıyla değerlendirerek tartışmaktadır. Türkiye'de her ne kadar zihinde oluşturduğu imge ile genellikle kentle ilgili bir görüntü oluştursa da mahallenin üç tür karşılığı bulunmaktadır. Bunlardan biri büyükşehir belediye örgütü bulunmayan illerdeki çok yerleşmeli köy idari alanlarında bulunanlardır. Diğerleri büyükşehir belediye örgütü bulunan illerdeki köyden dönüştürülen mahalleler ve bu mahallelere bağlı durumdakiler ile kasaba ve şehirlerin içinde yer alanlardır. Mahalle kavramının kullanımdaki bu çoklu görünümün yarattığı karışıkığı gidermek için konu nicel ve nitel araştırma yöntemleri kullanılarak yerleşme coğrafyası bağlamında örnekler üzerinden değerlendirilmiş ve öneriler geliştirilmiştir. Aynı şekilde yönetsel yapı açısından mahalle, muhtarlıklar baz alınarak Türkiye'nin yönetsel kurgusu içerisindeki yeri bakımından hem yetki hem de işlevsel yönden sorgulanmıştır. Bunun sonucunda da yönetsel yapı bakımında mahalleyle ilgili elde edilen bulgular doğrultusunda öneriler geliştirilmiştir. Çalışmanın son kısmında ise Türkiye'nin yönetsel hiyerarşisindeki konumuna yönelik teklif edilen değişiklikler uyarınca mahallenin sınırları ve optimal büyüklüğü konusunda ölçekler geliştirilmiştir. Belirlenen ölçeklerle mahallelerin optimal büyüklüğü mevcut mahalleler üzerinden örneklendirilerek değerlendirilmiş ve bu doğrultuda öneriler geliştirilmiştir.

Anahtar kelimeler: Mahalle, yönetsel coğrafya, yerleşme coğrafyası, idari yapı, optimal mahalle büyüklüğü

\section{ABSTRACT}

In Turkey, different contexts are recognized in terms of the settlement and administrative geography of the neighborhood concept. The multiplicity of the neighborhood (i.e., same name but different contexts), creates confusion. Thus, this study discusses the causes of neighborhood confusion by evaluating it in terms of settlement geography and administrative structure. The neighborhood, which generally creates a mental image of an urban location, is grouped into three types of equivalents. The first is located in multi-settled village administrative areas in provinces, where no metropolitan municipality organization exists. The second pertains to neighborhoods that were transformed from villages in metropolitan municipal provinces and those connected to these neighborhoods. The last type is those found in sections of towns and cities. The three types of equivalents of the concept of neighborhood create confusion. To resolve this issue, the study cited examples, evaluated the classification using the quantitative and qualitative research methods in the context of settlement and administrative geography, and presented recommendations. Lastly, the study developed scales for determining the boundaries and optimal sizes of the neighborhood.

Keywords: Neighborhood, administrative geography, settlement geography, administrative structure, optimal neighborhood size

Başvuru/Submitted: 04.03.2021 • Revizyon Talebi/Revision Requested: 11.05.2021 • Son Revizyon/Last Revision Received: 11.05 .2021 • Kabul/Accepted: 26.05 .2021

Sorumlu yazar/Corresponding author: Okan TÜRKAN / okanturkan@karatekin.edu.tr Atıf/Citation: Turkan, O. (2021). İdari coğrafya ve yerleşme coğrafyası açısından mahalle kavramı. Cografya Dergisi, 42, 229-250. https://doi.org/10.26650/JGEOG2021-891475 


\section{EXTENDED ABSTRACT}

Rural and urban settlements consist of various types of settlements, one of which is the neighborhood. It is a concept encountered in rural areas and also urban and semi-urban ones. The multiplicity of the neighborhood (i.e., same name but different contexts), creates confusion. This blurry position of the concept of neighborhood is a result of cultural processes and political decisions. Thus, this study aims to elucidate this unclear definition and to evaluate the concept of neighborhood in terms of settlement geography. In addition, this study discusses the neighborhood's position in the administrative structure of Turkey. This study simultaneously employed quantitative and qualitative methods. Data were analyzed using the relevant legislation, field surveys, statistical data, and field observations as primary sources. Moreover, analysis was extended to many secondary sources.

Today, all disciplines that conduct studies on neighborhoods in Turkey encountered problems. Three concepts of neighborhood are recognized according to settlement geography and administrative geography, which leads to confusion.

The types of neighborhoods are as follows:

1. Those in multi-settled village administrative areas in 51 provinces without metropolitan municipalities;

2. Those created by abolishing the legal entity of villages in 30 cities with metropolitan municipalities and their sub-neighborhoods; and

3. Those located in sections of cities and towns.

The commonality of these settlements is that they are called neighborhoods. In general, however, neighborhoods are classified according to settlement geography (i.e., urban and rural). In metropolitan municipal provinces, neighborhoods found outside cities exhibit rural characteristics in terms of socio-cultural and economic functions. These neighborhoods should be called villages pursuant to Law No. 6360. Such villages and neighborhoods connected to them in other provinces should be called rural neighborhoods, whereas those found in sections of cities should be identified as urban neighborhoods.

In terms of administrative geography, settlements with mukhtars and village elder councils are called villages, which are considered local administration units. However, settlements with mukhtars and boards of aldermen are called neighborhoods, which are not local government units. Neighborhoods lack a legal entity, budget, and executive power. In the context of settlement geography, neighborhoods of villages do not currently need mukhtars. As such neighborhoods are unable to gain village status; they are administratively affiliated with village governance. Furthermore, neighborhoods in metropolitan municipality provinces that were transformed from villages should be returned to village status and to their former positions by providing them legal entities similar to villages in the 51 provinces. After the transformation, villages may continue to obtain services from the district and metropolitan municipalities provided by the Special Provincial Administrations pursuant to Law No. 6360. However, several regulations should be formulated in the procurement of services from municipalities. Such regulations should include the rearrangement of fees in taxes, service fees, and certain changes in zoning in favor of the village. Although neighborhoods found in sections of cities are represented by mukhtars, they are not a type of local administration similar to villages. Nevertheless, neighborhood administration units and neighborhoods have the most effective unit potential, which can contribute to the development of local democracy. Activating this potential will strengthen local governments and participatory democracy by enabling neighborhoods to participate in administrative aspects. Toward this end, establishing neighborhood administration units as low-level local administration units in urban settlements and gaining legal personality are necessary requirements. In this context, legal and administrative arrangements should be established with neighborhood mukhtars to enable various units of municipalities to exercise authority and make decisions about the city. In the case of the realization of these proposals or the establishment of new neighborhoods, issues regarding optimal sizing should also be resolved among the existing neighborhoods. However, no criteria exist to determine the optimal size of urban neighborhoods in Turkey, such that disproportionate differences exist between neighborhoods in terms of spatial integrity, population, and surface area.

To determine the optimum size of neighborhoods three basic criteria should be considered, namely, population, surface area, and spatial integrity. The optimal scale for the population should be 5.000. This size is in accordance with the municipal law, results of comprehensive studies on mukhtars, and administrative structure. The basic scale used for determining the optimal size of an area for a neighborhood should be the walking distance of residents. This distance should be considered in terms of meeting their daily needs in 
the neighborhood. Therefore, the optimal area of neighborhoods should be between 20 and 50 ha. Moreover, various thresholds, such as natural and human thresholds, reduced the spatial integrity of neighborhoods in Turkey. Thus, spatial integrity should be considered in determining the optimal size of neighborhood. Preferably, any natural or distinct human thresholds that may create disconnection in the neighborhood should be eliminated and should only be limited to the boundaries of neighborhoods. 


\section{GÍRIŞ}

Yerleşme, insanlık tarihinden bağımsız olarak ortaya çıkan bir olgu olmayıp insanın varlığıyla mana kazanan bir kavramdır. İnsanın biyolojik varlığını devam ettirme güdüsü; yeme içme, dinlenme ve barınma ihtiyacını doğurmuştur. Dolayısıyla yerleşme insanın her türlü faaliyetini yürüttüğü mekânda varlığını sürdürmek için oluşturduğu barınma üniteleridir. $\mathrm{Bu}$ barınma üniteleri insanların biyolojik varlıklarını sürdürebilmek için yürüttükleri faaliyetlere uygun olan ortamlarda yer almaktadır. İnsanların dünyada yerleştikleri ve yerleşebilecekleri bütün alanlara ökümen alanlar denilmektedir. Ancak bu alanlar dünyanın tamamını değil belli kesimlerini kapsar (Özçağlar, 2009: 75; Taş, 2016: 16). Denizler, göller, kayalık alanlar, buz ve kum çölleri gibi alanlar yerleşmeyi sınırlandırırken iklim koşullarının uygun olduğu morfolojik açıdan fazla eğimli olmayan, su kaynaklarına yakın verimli toprakların bulunduğu kesimler ise yerleşmeye uygun olan alanlardır. Görüldüğü gibi özü itibarıla barınma fonksiyonuna sahip bir ve daha fazla barınağa sahip olan yerleşmeler insanların varlığını devam ettirebilecekleri uygun coğrafi koşullara sahip yerlerde bulunabilmektedir. Yerleşilen ve/veya yerleşilebilecek alanlarla insanın yürüttüğg̈ faaliyetlerin niteliği birbirine koşut olarak zaman içerisinde çeşitlenmektedir. İnsan önceleri temel olarak avcılık ve toplayıcılık yaptı̆̆ından göçebe bir yaşam sürmekteydi. Daha sonra ise bitki ve hayvanların kültüre alınmasıyla göçebe yaşam terkedilmiş, belirli bölgeler yerleşikliği zorunlu kılmaya başlamıştır. $\mathrm{Bu}$ değişime bağlı olarak insanın zaman içinde barınma için seçtiği mekânlar da farklılaşmaya başlamıştır. Bu bağlamda insanların temel ihtiyaçlarından biri olan barınma olgusu zaman içerisinde farklılaşarak geçici barınma yerlerinden kalıcı barınma yerlerine evrilmiş ve sonuçta yerleşme kavramı ile farklı türde yerleşme kalıpları ortaya çıkmıştır.

Temelde barınma sorununu çözen yerleşmeler, zaman içerisinde barınmanın yanında başta ekonomik ve sosyokültürel nitelikte olmak üzere birçok faaliyetin içerisinde yürütüldüğü mekân parçalarına dönüşmüşlerdir. Öyle ki günümüzde yerleşme denilince, temel işlevi durumundaki barınma olgusunu aşan ve barınma işlevini zihinde diğer faaliyetlerden sonra ikame eden bir olgu haline gelmiştir. Söz konusu faaliyetler geçim kaynaklarıla ilgili olup yerleşmelerin fonksiyonel özellikleri yerleşim birimlerinin tasnifinde ön plana gelmeye başlamıştır. Yerleşmeler fonksiyonlarına göre temelde hammaddeler üretimi, sanayi ve hizmet üretimi olmak üzere üç faaliyet türünün icra edildiği yerlerdir. Dolayısıyla yerleşmeler bu faaliyetlerin hangisinin baskın olduğu ve/veya faaliyetin yürütülme zamanına göre de sınıflandırılmaktadır. Bu bakımdan yerleşmeler faaliyetin zamanına göre sürekli ve dönemlik olarak sınıflandırılabilirken faaliyetin niteliğine göre ise kırsal ve kentsel olarak tasnif edilmektedir. Kırsal ve kentsel yerleşmeler kendi içlerinde çeşitli türde yerleşmelerden oluşmaktadır. Bunlardan biri olan ve aynı zamanda çalışmanın odağını oluşturan mahalle, hem kırsal hem de şehir ve kasabalardan oluşan kentsel yerleşmelerde karşılaşılan bir kavramdır.

\section{AMAÇ, YÖNTEM VE VERİ}

Çalışmanın kapsamını oluşturan mahallenin, belirtilen çoklu görünümü bazı karışıklıklar meydana getirmektedir. Gerek yerleşme gerekse yönetsel coğrafya içerisinde karşılaşılan mahalle kavramının bu bulanık konumu hem kültürel süreçlerin hem de politik kararların sonucunda meydana gelmiştir. Mahalle kavramında ortaya çıkan bu bulanıklığın berraklaştırılmasını amaçlayan çalışma, mahalle kavramını yerleşme coğrafyası açısından değerlendirmenin yanında Türkiye'nin idari yapısındaki yeri bağlamıyla da tartışmaktadır. Bu bakımdan çalışmanın ilerletilmesinde nicel ve nitel yöntem birlikte kullanılmıştır. Konuyla ilgili yasal mevzuat, yapılmış saha çalışmaları, istatistiki veriler ve arazi gözlemleri birincil kaynak olarak değerlendirilmiş, ayrıca da pek çok ikincil kaynak değerlendirmeye tabi tutulmuştur. Elde edilen bulgulara göre çalışmanın birinci bölümünde konu öncelikle yerleşme coğrafyası içerisindeki yeri bakımından değerlendirilmiştir. Çalışmanın ikinci bölümünde mahalle kavramı, idari yapı açısından Türkiye'nin yönetsel hiyerarşisindeki mevcut konumu üzerinden değerlendirilmiştir. Yönetsel yapı açısından mahalle, muhtarlık üzerinden değerlendirilerek gerek yerel gerekse merkezi yönetim bakımından yetki ve işlevleri yönünden ele alınmaktadır. Bu değerlendirmelerin sonucunda da mahallenin idari yapı içerisindeki yeriyle ilgili bazı öneriler getirilmiş̧ir. Çalışmanın üçüncü bölümünde ise Türkiye'nin yönetsel hiyerarşisindeki konumuna dair belirlenen öneriler doğrultusunda mahallenin sınırları ve optimal büyüklüğüne yönelik ölçütler geliştirilmiş ve belirlenen ölçütler örneklerle değerlendirilmiş̧ir.

\section{MAHALLE KAVRAMININ YERLEŞME COĞRAFYASINDAKİ YERİ}

Türkiye'de yerleşme olgusunu içeren herhangi bir çalışma yapan bir disiplin, mahalle kavramıyla farklı mekânsal düzey ve idari statüde karşılaşabilmektedir. Gerek coğrafya, idari bilimler, gerek şehir ve bölge planlama disiplinlerinin çalışma konuları içerisinde mahalle olgusu yer almaktadır. Günümüzde Türkiye'de mahalle kavramını içeren çalışmalar yürüten tüm disiplinler yerleşme coğrafyası ve yönetsel coğrafya açısından üç farklı 
mahalle kavramıyla karşılaşmaktadırlar. Bu durum hem yerleşme hem de idari yapı açısından bazı karışıklıklar oluşturmaktadır.

Söz konusu mahalleler şunlardır:

1. Büyükşehir belediyesi bulunmayan 51 ilde yer alan çok yerleşmeli köy idari alanlarındaki mahalleler

2. Büyükşehir belediyeli 30 ilde yer alan köylerin tüzel kişiliği kaldırılarak oluşturulan mahalleler ve bu mahallelere bağlı durumdaki mahalleler

3. Kasaba ve şehirlerin bölümleri durumunda olan mahalleler

\subsection{Büyükşehir Belediyesi Bulunmayan 51 İlde Yer Alan Çok Yerleşmeli Köy İdari Alanlarındaki Mahalleler}

Yerleşme coğrafyasında kullanılan üç farklı mahalle olgusundan biri, büyükşsehir belediyesi bulunmayan 51 ildeki köy idari alanlarında yer alan ve mahalle olarak adlandırılan yerleşmelerdir. Türkiye'de köy idari sınırları içerisinde çoğunlukla bir adet yerleşim alanı bulunmaktadır. 2020 yılı itibarıla söz konusu 51 ilde 18.294 köy idari alanı bulunmakta olup bu alan içerisinde 23.899 köy bağlısı yer almaktadır. Toplam köy idari alanı içerisinde sadece 7.496'sında birden fazla yerleşim alanı bulunmaktadır (https://www.e-icisleri.gov.tr, 2020). Birden fazla yerleşmeye sahip köy idari alanlarına çok yerleşmeli köy denilmektedir (Şekil 1 ve 2). Çok yerleşmeli köy

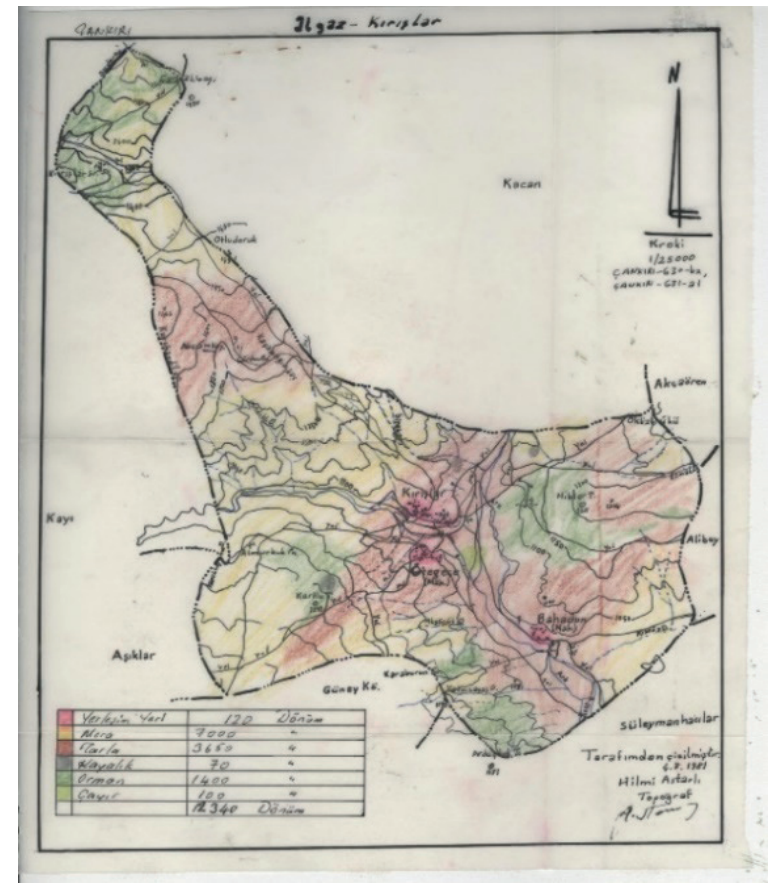

Şekil 1. Çankırı ili, Ilgaz ilçesi Kırışlar köyü idari alanı. Figure 1. Kırışlar village administrative area (Çankırı/llgaz). Kaynak: T.C. Tarım ve Orman Bakanlığı Arşivi. idari alanları içerisinde yer alan ve sürekli oturulan her bir yerleşme ünitesi idari yönden mahalle olarak isimlendirilmekte olup bunların tamamı resmi belgelerde mahalle olarak geçmektedir. Çok yerleşmeli köyler ile tek yerleşmesi bulunan köyler arasındaki yegâne fark köy idari alanı içerisindeki yerleşme sayısı olup başkaca bir fark bulunmamaktadır. Çok yerleşmeli köylerdeki her bir mahalle aslında bir köydür. Nitekim buralarda yaşayan insanların bir kısmı yaşadığı mahalleyi tanımlarken mahalleden ziyade köy olarak adlandırmaktadırlar (Özçağlar, 2009: 83-84). Çok yerleşmeli köy idari alanları içerisinde yer alan mahallelerden biri muhtarlığın bulunduğu yerleşme olup burası köyün yönetim merkezi durumundadır. $\mathrm{Bu}$ bağlamda muhtarlığın bulunduğu mahalleye merkez mahalle denilmektedir (Özçağlar, 2005: 6). Merkez mahalle genellikle diğer mahalle/lerden daha büyük olup çoğunlukla ona köy diğerlerine ise mahalle denilmektedir. Aslında bu mahallelerin her biri Osmanlı Dönemi'nde birer karye (köy) idi. Cumhuriyet Dönemi'nin yeni idari sisteminde karyelerin bir kısmı çok az nüfusa sahip olduğu için muhtarlık görevi ve tüzel kişilik verilmemiş olup bunlara mahalle denilmesi muhtarlığın bulunduğu merkez mahalleden ayırmak için olmalıdır. Mahalleli köy idari alanları içerisinde yer alan yerleşmelerde yürütülen ekonomik faaliyetler ve sosyokültürel yapı birbirinin aynısıdır. Arazide birden fazla yerleşmenin bulunması gerek jeomorfolojik gerekse de sosyokültürel süreçlerin etkisinin bir sonucudur (Taş, 2016: 208-210; Özçağlar, 2015: 123).

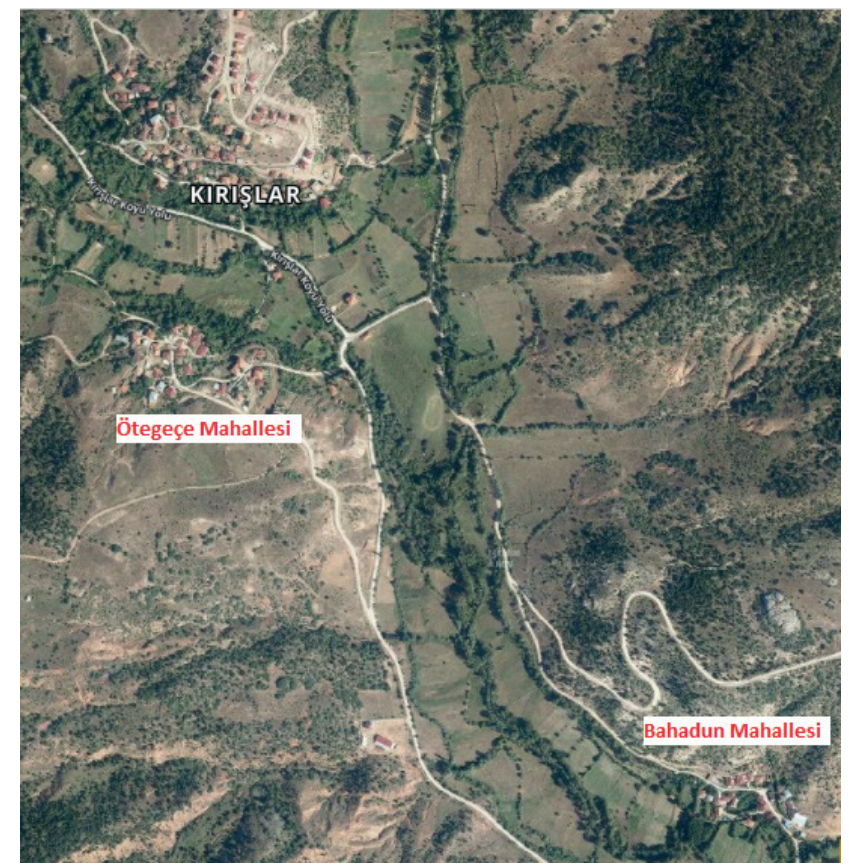

Şekil 2. Çankırı ili, Ilgaz ilçesi Kırışlar köyü idari alanındaki yerleşmeler. Figure 2. Settlements Kırışlar village administrative area. (Çankırı/llgaz). Kaynak: Harita Genel Müdürlüğü (atlas.harita.gov.tr,2020). 


\subsection{Büyükşehir Belediyeli 30 İlde Yer Alan Köylerin Tüzel} Kişiliği Kaldırılarak Oluşturulan Mahalleler ve Bu Mahallelere Bağlı Durumdaki Mahalleler

Bilindiği gibi 6 Aralık 2012 tarihinde Resmi Gazete'de yayımlanarak yürürlüğe giren ve 12 Kasım 2012 tarihinde TBMM'de kabul edilmiş olan 6360 sayılı Kanun ile büyükşehir belediyeli il sayısı 30'a çıkarılmıştır. Söz konusu kanunun hükümlerine göre büyükşehir belediyeli illerde yer alan köylerin tüzel kişiliği kaldırılmıştır. Böylelikle Türkiye'de sadece büyükşehir belediyesi bulunmayan illerdeki köylerin varlığ resmi anlamda devam etmiştir. 6360 sayılı Kanun öncesinde, Türkiye'de toplam nüfusun yaklaşık \%35'ini oluşturan 34.395 köyün nerdeyse yarısı olan 16.545 'inin tüzel kişiliği kaldırılmıştır. Aynı zamanda büyükşehir belediyeli olan illerdeki toplam 1089 ve diğer 51 ildeki nüfusu 2000'den az olan 559 belde belediyesinin de tüzel kişiliğine son verilmiştir. Büyükşehir belediyeli olmayan 51 ildeki beldeler köye, büyükşehir belediyeli illerdeki köy ve beldeler ise mahalleye dönüştürülmüştür. Söz konusu düzenleme ile köylerin \%47,2'si, belediyelerin \%54'ünün tüzel kişiliğine son verilerek bu yerleşmelerin ortak malları büyükşehir belediyelerine devredilmiştir. 6360 sayılı Kanun ile 30 büyükşsehir belediyeli ildeki sadece köy ve beldeler değil bu köylerin bağlısı durumundaki 20.237 mahallenin de idari statüsü değişmiştir (Dik, 2014: 77, 85-87; Özçağlar, 2015: 113). Bu yasa ile Türkiye'deki 30 ilde yer alan 16.545 köyün ve bunlara bağl1 olan mahallelerin tüzel kişiliğinin kaldırılması aynı zamanda bu illerde kırsal nüfusun da sıfırlanması anlamına gelmiştir. Nitekim Türkiye İstatistik Kurumu (TÜIK) verilerine göre söz konusu 30 büyükşsehir belediyeli ilde kırsal nüfus yer almamaktadır (biruni. tuik.gov.tr, 2020). Çünkü TÜIK'e göre -ki gerçekte de böyledirkırsal nüfusu sadece köyler ve köy bağlılarında ikamet eden nüfus oluşturur. $\mathrm{Bu}$ durumda kırsal yerleşmeler mahalleye dönüştürüldüğüne göre söz konusu 30 ilde kırsal nüfus yoktur ve kentli nüfus ise \%100'dür. Şüphesiz ki bu durum gerçeği yansıtmamaktadır. Gelinen noktada mahalleye dönüştürülen köyler ile kentlerdeki mahalleler bir bütün olarak mahalle statüsüne çevrildiği için bu illerdeki gerçek kentli ve kırsal nüfusun tespiti mümkün olmamaktadır. Kentsel ve kırsal nüfusun tespiti için yasa öncesi büyükşehir belediyeli illerdeki köylerin listesinin temin edilip kentsel mahallelerden ayılanması ve bunların kentsel doku dışında kalıp kalmadıkları uydu fotoğrafları üzerinde kontrol edilmesi gerekmektedir (Özçağlar, 2016: 271; Şenol, 2019: 53).

6360 say1lı Yasa ile mahalleye dönüştürülen yerleşmelerin tamamı aslen köy olup bunlar da kentlerin bölümleri durumundaki mahalle ile resmiyette aynı şekilde isimlendirilmektedir. Her ne kadar kaynakların bir kısmında köy tüzel kişiliği kaldırılarak mahalleye dönüștürülen yerleșmelere kırsal mahalle, șehirlerdeki mahallelere de kentsel mahalle gibi isimlendirme yapılsa da resmiyette böyle bir ayrım bulunmamaktadır. Nitekim ilgili yasa da bu iki mahalle tipini kentsel ve kırsal diye bir ayrıma tabi tutmamaktadır. 6360 sayılı kanunla meydana getirilen düzenleme uyarınca büyükşehir belediyelerinin hizmet bölgelerine dâhil edildikleri için tüzel kişilikleri lağvedilerek idari açıdan bağlı oldukları büyükșehir ilçe belediyesine mahalle olarak bağlanan köy yerleşmelerinin mahalle sanı almaları onları ne yerleşme ne de yönetsel hiyerarşide daha üst bir makama taşımamıştır. Dolayısıyla bu yerleşmelerin yapılarında ve işlevlerinde önemli bir farklılaşma meydana gelmemiştir. Bunun yanında geçmişte köy olarak adlandırılan yerleşmelerin mahallesi durumundaki 20.237 yerleşme için ise yasa ayrı bir tanımlamaya gitmemiştir. Bir başka ifadeyle bunlar yok sayılmıştır. Nitekim ilgili büyükşehir belediyelerinde bunlarla ilgili bir isimlendirme de bulunmamaktadır. Bu durumda söz konusu bağlılar teknik olarak mahallenin mahallesi gibi anlamsız bir durumda bulunmaktadır. Şekil 3 ve 4'te görüldüğü gibi Ankara ili Kızılcahamam ilçesi Eğerlibaşköyü Mahallesi'nin merkez mahallesi dışında Değirmenciler, Duraşar, Ortaköy ve Sarıçam olmak üzere dört mahallesi daha yer almaktadır. Bunlar için idari hiyerarşiyi yansıtacak herhangi bir yasal belirleme yapılmamıştır. Böyle olunca Duraşar adlı yerleşme teknik olarak Eğerlibaşköyü Mahallesi'nin Duraşar Mahallesi olarak adlandırılmak durumundadır. Yani mahallenin mahallesi... Ancak T.C. İçişleri Bakanlığı Nüfus ve Vatandaşlık İşleri Genel Müdürlüğünde olduğu gibi bazı kamu kurumlarında bu mahalleler küme evleri olarak tanımlanmaktadır. Bu tanımlama 2006 yılında Resmî Gazete'de yayınlanarak yürürlüğe giren 26245 sayılı Adres ve Numaralamaya İlişkin Yönetmeliğin 4. maddesi uyarınca bir sokağa bağlanması mümkün olmayan, dağınık durumdaki birden fazla binanın olușturduğu yerleșim alanını belirtmek için yapılmaktadır. Eskiden köylerin mahallesi olan bu yerleşim yerleri için küme evleri denilmesinin resmiyet kazanması durumunda, kentsel mekânların bölümleri durumundaki henüz imar süreçleri tamamlanmamış yerlerle karıştırılma durumu söz konusu olacaktır. Dolayısıyla yerleşme coğrafyası açısından büyükşehir belediyeli illerdeki köyden dönüştürülen mahallelere eskiden olduğu gibi köy ve bunlara bağlı olan sürekli yerleşim yerlerine ise yine mahalle denilmesi gerekmektedir.

\subsection{Kasaba ve Şehirlerin Bölümleri Durumunda Olan Mahalleler}

Farklı disiplinlerce çok çeşitli tanımlar yapılan mahalle, kelimenin kökeni itibarıyla mahal ile aynı kökten türetilmiş olup 

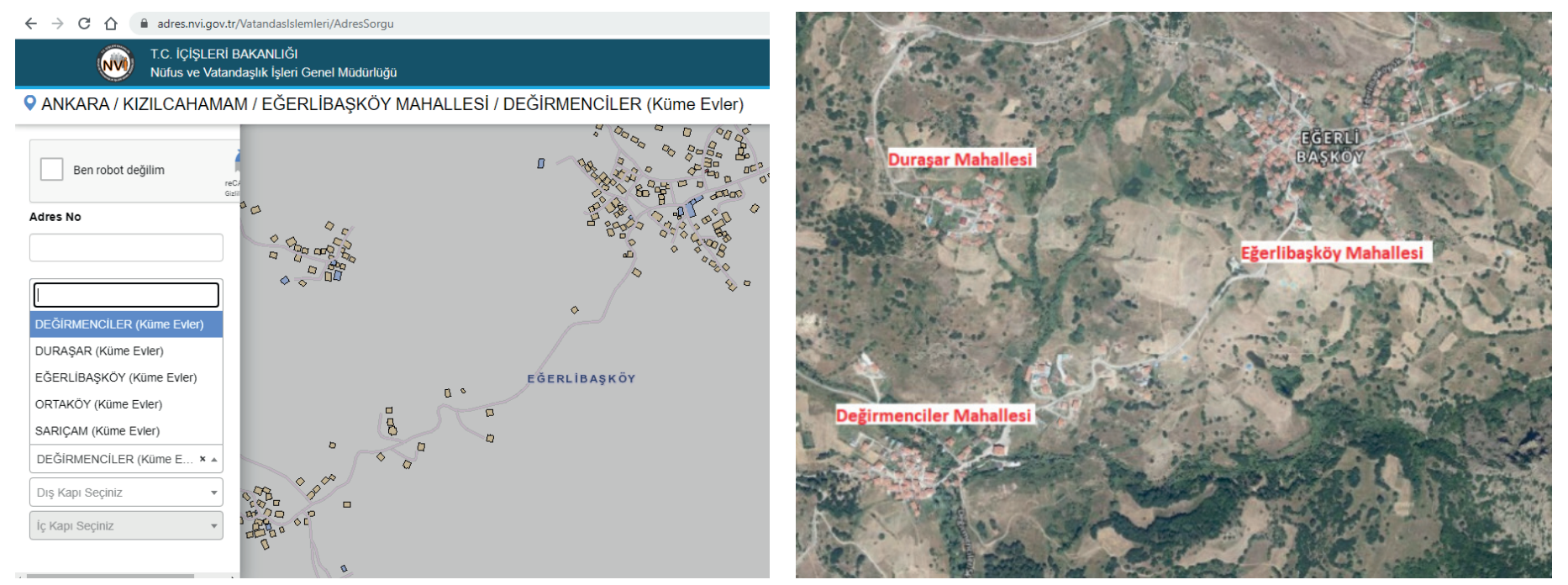

Şekil 3 ve Şekil 4. Ankara ili, Kızılcahamam ilçesi Eğerlibaşköy mahallesinde yer alan mahalleler.

Figure 3 and Figure 4. Neighborhoods in Eğerlibaşköy neighborhood (Kızılcahamam/Ankara)

Şekil 3. Kaynak: T.C. İçişleri Bakanlığı Nüfus ve Vatandaşlık Işleri Genel Müdürlüğü (adres.nvi.gov.tr, 2020).

Şekil 4. Kaynak: Harita Genel Müdürlüğü. (atlas.harita.gov.tr, 2020).

önceleri konaklanan yer anlamında kullanılmıştır. Daha sonraları ise sözcük anlamsal zenginlik kazanarak kırsal yerleşmelerdeki mahalle kavramından daha baskın bir biçimde özelleşerek kentlerin bir semti anlamında kullanılmış ve Türkçeye geçmiştir (Bayartan, 2005: 94-95). Nitekim Türk Dil Kurumu'nun web sitesindeki Güncel Türkçe Sözlüğe göre mahallenin bir şehri, kasabayı ya da büyük bir köyü oluşturan her bir parçası olarak tarif edilmesi sözcüğün kentsel mekânlarla daha çok ilgili olduğunu göstermektedir (https://sozluk.gov.tr, 2020). Kentlerin en küçük birimleri olan konutlar ve sokak sistemlerinin birleşerek oluşturduğu mahalleler, yönetsel, sosyal, kültürel ve ekonomik fonksiyonları içeren çeşitli türdeki faaliyetlerin icra edildiği en küçük yönetsel yapılanmadır. Başka bir ifadeyle şehirler mahallelere, mahalleler sokak ve caddelere, onlar da konut ve binalara bölünürler (Bayartan, 2005: 96). Mahalle denilince insanların zihninde oluşan imge çoğunlukla kentsel alanlarla ilgilidir. Özellikle ülke toplam nüfusunun 3/4'ünün kentsel yerleşmelerde oturduğu düşünüldüğünde kırsal yerleşmelerdeki mahalle olgusu, insanların zihninde öncelikle beliren bir unsur olmaz. Bu anlamda mahalle fiziksel unsurlarla sinırları belirlenmiş kentsel mekânların bir alt birimi olarak değerlendirilebilir (Alada, 1989:VII). Bir başka tanıma göre mahalle, şehirler içerisindeki meskûn alanlarda yer alan ve buralarda ikamet eden insanlara yönelik bazı hizmetleri sunan şehirlerin en küçük idari birimleridir (Aytaç, 1995: 29). Mahalle, toplumsal ve kültürel anlamda sosyolojik bir karşıllı̆a sahip olup ev ve sokaklardan oluşan ruhsuz bir birim değil, öznesi insan olan dinamik bir yapıdır (Alver, 2013: 21).
Sınırları belli olan bir mekânı müşterek olarak paylaşan insanların yaşadığı sahalar olan mahalleler, temelinde tarihi, politik, idari ve aidiyet duygusunun geliştiği sosyokültürel özellikleri barındıran yerleşim birimleri olarak da tarif edilebilmektedir. Bu bağlamda aynı mahallenin sakinleri mahalle içerisinde yer alabilen eğitim, sağlık, inanç, sosyal tesis ve rekreasyon alanları gibi ortak kullanıma haiz olan yerlerde karşılaşarak veya bir araya gelerek sosyal, kültürel ve/veya ekonomik ilişkiler geliştirirler. Her ne kadar günümüzde söz konusu durum kentsel mekânlarda erozyona uğramış olsa da bazı şehirlerde hala bu tür ilişkilerin sürdürülebildiği görülebilmektedir. Mahallelerdeki ortak kullanılan yerlerde geliştirilebilecek olan ilişkilerin sonucunda temelde mahalle ve nihayetinde yaşanılan kentte ortak yaşama kültürünün oluşma zemini inşa edilebilmektedir (Erdagöz, 2012: 60-61). Yasal zeminde ise mahalleyi 5393 sayılı Belediye Kanununun 3. maddesi tanımlamakta olup buna göre mahalle; belediye sınırları dâhilinde gereksinimleri ve öncelikleri birbirine benzeyen ve ikamet edenlerce aralarında komşuluk ilişkisi bulunan yönetsel birimdir. Aynı yasanın 9. maddesinde bu birimin kimler tarafından yönetileceği de açıklanmış olup hükme göre mahallenin muhtar ve ihtiyar heyetince idare edileceği belirtilmiştir.

Görüldüğü gibi kentsel ve kırsal bölgelerde üç farklı mahalle kavramı ile karşılaşılmaktadır. Dolayısıyla literatürde mahalle sözcüğünün bu üç farklı mahalleden hangisine karşı1ık geldiği ancak ilgili metnin içeriği değerlendirildiğinde 
anlaşılmaktadır. Aslında 6360 sayılı Kanun öncesinde mahalle sözcüğü sadece köy bağlısı durumundaki mahalle ile şehirlerin bölümleri olan mahallere karşılık gelmekteydi. Oluşabilecek karışıklıkların giderilmesi hususunda da literatürde köy bağlısı durumundaki mahalle için köy mahallesi, şehirlerin bölümleri olan mahalleler için ise yalnızca mahalle kavramı yaygın bir biçimde kullanılmaktaydı. Kanunla birlikte büyükşehir belediyeli illerdeki tüm köylerin tüzel kişiliği kaldırılarak mahalleye dönüştürülmüştür. Oluşan bu yeni durumla birlikte kırsal ve kentsel mahalle kavramları dolaşıma girmeye başlamıştır. Kırsal mahalle sözcüğü tüzel kişiliği ortadan kaldırılan köyler yerine, kentsel mahalle sözcüğü ise şehirlerin bölümleri olan mahalleler yerine kullanılmaya başlamıştır. Bu durumda tüzel kişiliği kaldırılan köylerin bağlısı durumundaki mahalleler görünmez olmuş ve yerine onları tanımlayacak bir kavram tam anlamıyla oluşturulamamıştır. $\mathrm{Bu}$ anlamda hâlihazır durumda köy bağlısı olan yerleşim birimi tarif edileceği zaman X ilinin Y kırsal mahallesinin Z mahallesi gibi anlamsız ve zorlama bir kullanım ortaya çıkmaktadır. Söz konusu durum bir problem olarak görünmeye başlanmış olmalı ki PTT, Doğal Afet Sigortaları Kurumu ve Nüfus ve Vatandaşlık İşleri Genel Müdürlüğü gibi kuruluşların web sitelerinde köy bağlısı durumundaki mahalleler küme evleri olarak adlandırılmaktadır. Ankara ilinde verilen örnek gibi Trabzon ili Akçaabat ilçesi Akdamar Mahallesinin bağlıları durumundaki Kıran, Emir Ali, Hapipli, Mergibesli ve Özakdamar mahalleleri belirtilen kurumların sistemlerinde de küme evleri olarak tanımlanmıştır. Küme evleri tanımlaması ise söz konusu mahallelerin, şehirlerde henüz imar süreçleri tamamlanmamış yerlerle karıştırılmasının önünü açmaktadır. Bu karışıklığın çözüme kavuşturulmasında eskiden olduğu gibi büyükşehir belediyeli illerdeki tüzel kişilikleri kaldırılarak mahalleye dönüştürülen köylere adlarının iade edilmesi bir yol olarak ortaya çıkmaktadır. 6360 sayılı Yasa ile köy tüzel kişiliği kaldırılarak mahalle statüsüne dönüştürülen köylerin, yasanın yürürlüğe girdiği dönemden günümüze kadar geçen süre içerisinde sosyokültürel ve ekonomik yapısında anlamlı bir değişim meydana gelmemiş̧ir. Kısaca bu yerleşmeler yasadan önce de sonra da geleneksel köy yerleşmeleri olmaya devam etmiştir. Bu bağlamda söz konusu yerleşmelerin gerçekçi bir yaklaşımla eskiden olduğu gibi köy yerleşmesi olarak değerlendirilmesi daha doğru olacaktır. Böylelikle, bunların bağlısı durumundaki mahalleler köy mahallesi veya kırsal mahalle olarak, kentlerdeki mahalleler ise mahalle veya kentsel mahalle olarak tanımlanabilir. Bu sayede olası karışıklıkların önüne geçildiği gibi yerleşme hiyerarşisi açısından da doğru bir sınıflama yapılmış olur.

\section{MAHALLE KAVRAMININ IDDARİ COĞRAFYADAKI YERI}

$\mathrm{Bu}$ bölümde idari coğrafya açısından önemli bir olgu olan mahalleler idari yapı yönünden incelenecek ve bu hususta bazı öneriler geliştirilecektir.

\subsection{Büyükşehir Belediyesi Bulunmayan 51 İlde Yer Alan Çok Yerleşmeli Köy İdari Alanlarındaki Mahalleler}

Büyükşehir belediyesi bulunmayan illerdeki köy idari alanları içerisinde 23.899 köy bağlısı yer almaktadır. Bu köy idari alanlarının 7.496'sında birden fazla yerleşim alanı bulunmaktadır. Bunun yanında büyükşehir belediyeli illerdeki köyden dönüştürülen mahallelere bağlı olan 20.237 yerleşme bulunmaktadır. Böylece mevcut durumdaki köylerin ve köyden dönüştürülen mahallelerin sürekli veya dönemlik toplam 44.136 adet bağlı yerleşmesi bulunmaktadır. Bir köyün idari alanı içerisinde kalan ve sürekli iskâna tabi olan her bir kırsal yerleşme idari coğrafya bakımından mahalle olarak isimlendirildiğinden bu yerleşmelerin büyük bir kısmını mahalleler oluşturmaktadır. Söz konusu mahalleler veya bağlılar çoğunlukla köyden daha küçük yerleşmeler olduklarından bunlara ait bir muhtarlık birimi bulunmamaktadır. Bu mahalleler yakın veya uzak bir köye veya köyden dönüştürülen mahalleye idari anlamda bağlı durumdadırlar. Dolayısıyla köylere bağlı mahallelerinin ayrı bir yönetim yapısı veya yönetsel işlevleri bulunmamaktadır (Özçağlar, 2015: 75; Kavruk, 2018: 15). Bu mahalleler yönetsel işlevlerle ilgili hizmet alımını bağlı bulundukları muhtarlıktan rahatlıkla temin edebildikleri için ayrı bir muhtarlık birimi oluşturulmasına gerek yoktur.

\subsection{Büyükşehir Belediyeli 30 İlde Yer Alan Köylerin Tüzel Kişiliği Kaldırılarak Oluşturulan Mahalleler ve Bu Mahallelere Bağlı Durumdaki Mahalleler}

Türkiye'de köylerle ilgili meydana gelen önemli değişimlerden biri 2012 yılında kabul edilen 6360 sayılı Yasa olup bu kanun ile 30 ilde yer alan tüm köy ve beldelerin tüzel kişiliği kaldırılarak bağlı bulundukları ilçenin mahallesi durumuna getirilmişlerdir. İlgili yasanın gerekçesi olarak sıralanan birçok maddenin yanında büyükşehir sınırları dâhilindeki yerel yönetimlerce yapılan küçük ölçekli planların bütüncül bir anlayışla tüm büyükşehir sınırlarını kapsayan makro politikaları belirleyen bir zeminde ele alınamaması gösterilmiş̧ir. Ayrıca böyle yerlerde çok sayıda yerel yönetimin bulunmasının çok başlı bir yap1 ortaya koyması, gerekli planlama ve koordinasyonun oluşturulamayarak, ölçek ekonomisinden 
yeterince yararlanılamadığı ve kaynak israfi doğurduğu belirtilmiştir. Bunun yanında çevre, ulaşım ve sanayi alanında artan sorunlarla belde belediyeleri ve köyler gibi küçük ölçekli mahalli idarelerin baş edemeyeceği, kaynakların etkin ve yerinde kullanılamayarak bu durumun küçük yerleşim birimleriyle büyükşehirlerde yönetim sorunlarına yol açtığı belirtilmiştir. Meydana gelen sorunlara çözüm olacak uygun büyüklükte yerel yönetim eksikliği olduğu vurgulanarak halkın beklediği kaliteli hizmet sunumunun ancak güçlü yerel yönetimlerce sağlanabileceği söz konusu yasanın ana dayanakları olarak sunulmuştur (https://www.tbmm.gov.tr 20.12.2020). Bu yasanın, çalışmanın odağını oluşturan kısmını, atıfta bulunulan diğer kanunlarla birlikte köyden dönüştürülen mahallelerde meydana gelen değişim oluşturmaktadır. İlgili yasada orman köylerine ve orman köylüsüne tanınan hak, sorumluluk ve ayrıcalıkların devam edeceği, köyden dönüşen mahallelerce kullanılan yaylak, kışlak ve mera gibi yerlerden mahalle sakinlerinin istifade etmeye devam edeceği belirtilmiştir. Bunun yanında köyden dönüştürülen mahallelerde vergi, harç ve katılım paylarının 5 yıl boyunca alınmayacağı, içme ve kullanma suları için tahsil edilecek bedelinin yine aynı süre zarfında en düşük tarifenin $\% 25$ 'ini geçmeyeceği de belirtilmiştir.

Kanun tasarısı sunulduğunda ve yasalaştıktan sonra 6360 sayılı Kanuna yönelik hem siyaset kurumundan hem de akademik camiadan önemli oranda itiraz ve eleştiri yöneltilmiştir. Çalışmanın yazarının da katıldığı söz konusu eleştiriler hukuksal, idari ve sosyokültürel boyutlar başta olmak üzere çok yönlüdür. $\mathrm{Bu}$ kısımda ilgili eleştiriler köyden dönüştürülen mahalleler bağlamıyla değerlendirilecektir. 6360 sayılı Yasanın maddeleri ve meydana getirdiği değişim hukuksal olarak değerlendirilip Anayasa'ya aykırı olduğu gerekçesiyle tenkit edilmiştir (Gözler, 2013: 39; Özer, 2013: 117-118; Dik, 2014: 96). Bunun yanında yasa, Yerel Yönetim Özerklik Şartı'na aykırılık açısından ve yerel demokrasinin işlerliği gereğince de eleştirilmiştir. Avrupa Yerel Yönetimler Özerklik Şartı'nın 5. Maddesinde, yerel yönetimlerin sınırlarının değiştirilmesinde o bölgede yaşayan halka referandum yoluyla danışılması gerekliliği bulunmasına rağmen böyle bir uygulamaya gidilmeden köy ve belediyelerin kapatılması doğru kabul edilmemektedir (Karaarslan, 2013: 149; Zengin, 2014: 111; Kara, 2016: 257; Ünal ve Erol, 2019: 92). Söz konusu yasanın hazırlanmasında yerel yönetimler içerisinde sadece büyükşsehir merkeze alınmış ve yasanın kentsel rant odaklı ve uluslararası piyasa koşullarının belirleyiciliği ve isteklerine yönelik olduğu belirtilmektedir (Zengin, 2014: 115). Büyükşehir belediyelerinin hizmet alanı bu yasa marifetiyle il sınırına dayanmıştır. Dolayısıyla hizmet veren ve alan arasında mesafe mefhumu devreye girerek hizmet maliyetlerini artıracağ 1 birçok araştırmacı tarafından vurgulanmıştır (Çalcalı, 2014: 65; Gözler, 2013: 81; Çetin vd., 2016: 193; Genç, 2014: 8-9; İzci ve Turan, 2013: 135; Kaymal, 2017: 1155; Yüksel, 2016: 745; Gezgüç vd., 2016: 1682). İl merkezine olan uzaklığı 250 km’yi aşan, Anamur'a bağlı Lale, Güngören, Anttlı ve Karaağa mahallelerinde olduğu gibi diğer illerde de buna benzer mesafelerdeki yerleşim birimlerinin büyükşehirden bazı hizmetleri beklemesi merkeziyetçi bir yönetim anlayışının tezahürü olup bu durum yerinden yönetim ve/veya hizmetlerde halka yakınlık ilkesiyle uyuşmamaktadır. Dolayısıyla 6360 sayılı Kanun yerelleşme yerine merkezileşmeye yönelik eğilimleri artırmıştır (Kara, 2016: 256; Koç, 2018a: 138). İlgili kanun sadece idari yapılanmada değişim meydana getirmemiş aynı zamanda seçim çevreleri ve yapısında da değişime neden olmuştur. Bu durum yasanın yerel seçim sonuçlarını etkileyerek iktidar lehine bir netice getirmek üzere hazırlandığı eleştirilerine de maruz bırakmıştır (Safi ve Kurşuncu, 2019: 66; Çolak vd., 2017: 19; İzci ve Turan, 2013: 130). Saha araştırmalarında büyükşehir belediyesi ve/veya büyükşsehir ilçe belediyesini yöneten siyasi irade ile köyden dönüştürülmüş mahallelerin siyasi tercihlerinin farklı olması durumunda partizanca tavir takınıldığ edilmiştir (Göküş ve Alptürker, 2016: 83; Aydın, 2018: 167, 208; Gezgüç vd., 2016: 1673). Büyükşehir belediyelerinin hizmet alanının il sınırıyla çakıştırılması belediyeleri daha geniş bir ölçekte hizmet üretme durumunda bıraktı̆̆ 1 halde kırsal kesimden yeterli vergi geliri tedarik edemeyecek olması ve bunun yanında köyden dönüştürülen mahallelere de ek vergi yükü getirmiş olması da ayrı bir sorun olarak not edilmektedir (Ünal ve Erol, 2019: 95; Avşar, 2020: 230; Sağırekmekçi, 2015: 84; Çavuşoğlu ve Lamba, 2020: 138; Genç, 2014: 10; Gezgüç vd., 2016: 1682).

Köy tüzel kişiliğinin kaldırılmasıyla, köylerde yaşayan halkın temsil yapılanması, birlikte yaşadıkları köy sakinleri arasından doğrudan seçerek oluşturdukları köy ihtiyar meclisleri lağvedilerek ortadan kaldırılmıştır. Bu anlamda köylerde yaşayan insanların yaşadığı yerler mahalle olarak tanımlandıkları için halkın demokratik temsili yalnızca belediye meclisi üyeleri üzerinden tarif edilmektedir (Zengin, 2014: 111; Çavuşoğlu ve Lamba, 2020: 130; Karaarslan, 2013: 149; Dik, 2014: 94). Hâlbuki yasa öncesinde temsil durumu, aynı yerleşim biriminde yaşayan, halkın bildiği, doğrudan ilişkiye geçebileceği, ortak sorunları ve süreçleri yaşayan insanlardan oluşurken yeni durumda belediye meclis üyelerinin böyle bir özelliği yoktur. Hatta önemli bir kısmı herhangi bir köyden dönüştürülmüş mahalleye de uğramamıştır. Türkiye İstatistik Kurumu (TÜIKK) verilerine göre 6360 sayılı Kanun'un kabul edildiği tarih olan 2012 yılında toplam nüfusun \%77,3'ü il ve ilçe merkezlerinde 
yaşamaktaydı (data.tuik.gov.tr, 2020). TÜİK, il ve ilçe merkezlerini şehir kabul ettiğinden bu oran Türkiye'deki şehir nüfusunun oranı olarak literatürde kullanılmaktadır. Gerçekte bütün ilçe merkezleri coğrafi anlamda şehir olmasa da TÜİK'in bu belirlemesi pratik bir sonuç doğurduğu için birçok araştırmada kullanılmıştır. Ancak aynı kurumun kent ve kır ayrımındaki 2013 yılına ait verilerine bakıldığında nüfusun \%91,3'ünün il ve ilçe merkezlerinde yaşadığı görülmektedir. Dolayısıyla bir yıl içinde şehir nüfusunda 14 puanlık bir değişim gerçekleşmiştir ki bu sonuç bilimin doğasına aykırı bir durumdur. Elbette oranın bu şekilde değişmiş olması büyükşehir belediyeli illerdeki köylerin tüzel kişiliğinin kaldırılarak mahalleye dönüştürülmesinin sonucudur. Mahalle kavramı da ilgili kurum için kentsel bir birim olduğundan ve söz konusu illerde de köy kalmadığ 1 için kırsal nüfus yoktur. Bu bağlamda büyükşehir belediyeli illerde kentli nüfus \%100'dür. Büyükşehir belediyeli illerde yer alan mahallelerin hangisinin köyden dönüştürülmüş, hangisinin kentin bölümü durumundaki mahalle olduğu TÜİK verilerinden anlaşılmadığı için gerçek anlamda kent ve kır ayrımı yapılamamakta ve bunların nüfusları da kolaylıkla hesaplanamamaktadır. Hesaplama, ancak önceki bölümde açıklandığı gibi bu illerdeki eski köy listeleri ve uydu fotoğrafları yardımıyla yapılabilmektedir (Özçağlar, 2016: 271). Kırsal nüfus ve kentsel nüfus ayrımı konusunda resmi makamlarca yapılmış herhangi bir belirlemeye şu ana kadar rastlanılmamıştır. Bu durumda büyükşehir belediyeli illerde gerçekte kent neresidir, nerede başlar ve biter, nüfusu nedir gibi sorulara ne yazık ki cevap bulunamamaktadır. Kır ve kent mekânlarının nüfuslarının bilinmesi ve yıllar arasında nüfus hareketlerinin mekânsal bağlamda takip edilmesi kır ve kente dair oluşturulacak olan planlamalar için elzemdir. Dolayısıyla ilgili yasa bu kontekst üzerinden de sorunlu görülmektedir (Çopuroğlu, 2017: 22-23; Çavuşoğlu ve Lamba, 2020: 128; Dik, 2014: 78; Özçağlar, 2016: 291; Şenol, 2019: 62; Bekdemir, vd., 2014: 296). Büyükşehir belediyesi hizmet alanı sınırı ilin tamamı haline getirildiğinden imar mevzuatına kırsaldaki mera, çayır, bağ, bahçe ve diğer türde tarım alanları da girmektedir. Kırsal alanların imar mevzuatına tabi olması buralarda yaşayan insanlar için farklı düzlemde sorunlar meydana getirebilecektir. Bu bakımdan tarım ve hayvancıllğa dayalı üretimde düşüş, mera ve tarımsal arazilerin imara açılmak suretiyle amaç dışı kullanımının önünün açıldığı yönünde değerlendirmeler bulunmaktadır (Yılmaz ve Kaypak, 2017: 417; Avşar, 2020: 80; Karaarslan, 2013: 149).

Coğrafya disiplininde köy kavramının yönetsel ve yerleşme coğrafyası bakımından iki karşılığı bulunmaktadır. Yönetsel coğrafya açısından köy, bir alanı ifade ederken yerleşme coğrafyasında ise kırsal yerleşme birimini ifade etmektedir
(Özçağlar, 2015: 72). Yönetsel coğrafya açısından; sınırları belli bir arazi parçası içerisinde sürekli ve/veya dönemlik kırsal yerleşmeleri bulunan, halkın çoğunlukla birincil ekonomik faaliyetlerle uğraştığı, seçimle işbaşına gelen muhtar ve ihtiyar meclisince yönetilen idari alana köy yönetsel alanı denir. Bu yönetsel alan içerisinde yer alan yönetim merkezi durumundaki yerleşmeye de köy denir. Köyler, sosyal yapı itibarıyla toplumsal bağların güçlü, ortak kültürel mirasa ve niteliğe sahip insanların birlikte yaşadığı, mütevazı ve sakin yaşam tarzının baskın olduğu alanlardır (Bayar ve Karabacak, 2020: 88). Durum böyleyken günümüzde bu tanıma sahip olan yerleşme ve yönetsel alan sadece büyükşehir belediyesi bulunmayan 51 ilde yer almaktadır. Diğer 30 ilde bu nitelikte yerleşmeler ve alanlar bulunsa da 6360 sayılıYasaile resmiyette böyleyerleşme ve alan bulunmamaktadır. $\mathrm{Bu}$ yerleşmelerin yasayla mahalleye dönüştürülmesi gerçekte bu illerde kırsal alanlar ve köy yerleşmeleri olduğu gerçeğini değiştirmemektedir. Ancak ilgili yasa Türkiye'de kırsal kesimde gerek yerleşme özellikleri gerek sosyokültürel ve ekonomik yapıları aynı olduğu halde büyükşehir belediyeli iller ile olmayanlar arasında iki farklı idari yapı meydana getirmiş̧tir. Buna karşın tüm illerdeki kırsal yerleşmelerin idari anlamda tek ortak yönü yönetiminde muhtarın bulunmasıdır. Her iki grupta yer alan kırsal yerleşmelerde gündelik yaşam her yönüyle aynı olduğu halde büyükşehir belediyeli illerdeki kırsal yerleşmelerin yönetsel yapılanma açısından 51 ildeki türdeşlerinden farklı mevzuata sahip olduğu görülmektedir. İdari anlamda her iki grup ildeki kırsal yerleşmelerde yönetim organı açısından farklılıklar vardır. Köylerde ihtiyar meclisleri, köyden dönüştürülen mahallelerde ise ihtiyar heyetleri bulunmaktadır. Ayrıca bu kırsal yerleşmelerde yönetimlerin kurumsal yapıları da farklıdır. Nitekim 51 ildeki köy, Anayasa'yla tanımlanmış kamu tüzel kişiliği olan bir birimken büyükşehir belediyeli illerdeki köyden dönüştürülen mahallelerin tüzel kişiliği yoktur. Köy yönetimi kamu kurumu olup aynı zamanda bir yerel yönetim birimiyken mahallelerin böyle bir statüsü yoktur. Bunlara ek olarak özerk bir yerel yönetim kurumu olan köylerin icraatçı yapıları, kendi bütçeleri, salma ve imece gibi özel gelir kaynakları bulunurken mahallerin böyle bir yönü yoktur. Köyler Anayasa’ya dayanarak merkezi idare tarafindan kurulabilirken mahallenin kuruluşunda, sınırlarında ve sınır değişikliklerinde yetkili kurum belediyelerdir. Mahallenin resmiyette ne anlama geldiği yani tanımı 5393 sayılı Belediye Yasası'nın 3. maddesinin D bendinde belirlenmiştir. Buna göre mahalle; belediye sınırları içinde, ihtiyaç ve öncelikleri benzer özellikler gösteren ve sakinleri arasında komşuluk ilişkisi bulunan idarî birim olarak tanımlanmaktadır. Burada açıkça mahallenin kentsel yerleşmenin bir bölümü olduğu vurgulanmaktadır ki köyden dönüştürülen mahalleler bu tanıma uymamaktadır. Ayrıca bu yasa maddesinde mahalle için ihtiyaç 
ve öncelikleri benzer özellikler gösteren ifadesi yer almakta olup şehre kilometrelerce uzaktaki eskiden orman köyü veya ovada tarımsal faaliyetleri baskın olan ya da hayvancılık ile geçinen köyden dönüştürülmüş mahalle ile yasadaki kentsel yerleşmenin bölümü durumundaki mahallenin ortak yönü bulunmamaktadır.

Yasanın geçmesinin üzerinden yedi, uygulamaya girdiği yerel seçim tarihinden günümüze kadar ise altı yıl geride kalmıştır. Bu süre zarfinda çeşitli saha çalışmalarında söz konusu yasanın köylerde nasıl algılandığı ve değerlendirildiğiyle ilgili tespitler bulunmaktadır. İncelenen çalışmalardan bazıları yasanın yürürlüğe girdiği tarihe yakınken bazıları ise günceldir. Yapılan çalışmaların sonuçları arasında, köyden dönüştürülmüş mahalle muhtarları tarafından memnuniyet duyulan hususlar varsa da çoğunlukla memnuniyetsizliğin daha fazla olduğu sonuçlar bulunmaktadır. Bilindiği gibi 6360 sayılı Yasa, kırsal alandaki yerleşmelere hizmet götürme açısından hem büyükşehir hem de ilçe belediyelerine görev yüklemektedir. Muhtarların önemli bir kısmı köy, ilçe belediyesi ve/veya büyükşehir belediyesi arasında siyasi görüş ayrılıklarının hizmet alımını yavaşlattı̆̆ını veya engellediğini belirtmektedir. Muhtarlarca aktarılan taleplerin işleme alınmasında hakkaniyetli davranılmadığı, siyasi veya sosyal ilişkiye göre taleplerin değerlendirildiği ifade edilmiştir. Hatta ilçe belediyesi ile büyükşehir belediyesi aynı siyasi partinin mensubu olsalar bile görüş ayrılıkları veya siyasi rekabet nedeniyle hizmet alımında sorunlar yaşandığı aktarılmıştır (Aydın, 2018: 197; Tekçe, 2018: 119; Susta, 2018: 128). Yasanın yürürlüğe girdiği tarihten itibaren ilçe ve/veya büyükşehir belediyelerinden yeterli hizmet alınamadığ 1 saha çalışmalarının önemli bir kısmında tespit edilmiştir. Bazı belediyelerin çöp toplama ve kar temizleme görevlerini ifa etmede bile yetersiz kaldığı belirtilmiştir (Aydın, 2018: 197). Ayrıca ilgili belediyelerden altyapı ve kanalizasyon gibi hususlarda da hizmet alınamadığı ifade edilmiştir. Bazı araştırmalarda da muhtarlar, İl Özel İdareleri faal iken Köylere Hizmet Götürme Birlikleri'nden aldıkları hizmetlerin belediyeler tarafından layıkıyla yerine getirilmediğini vurgulamışlardır (Susta, 2018: 139). Bu bağlamda hizmetlerden yoksunluk, yapılan hizmetlerin de yetersiz ve eksik bulunması, belediyelere iletilen taleplerin karşılanmasında sorunlar çıkması, yasayla meydana gelen dönüşümün işlevselliğinin hizmet alanlarca oluşmadığını göstermektedir (Aydın, 2018: 197-198; Gezgüç vd., 2016: 1682; Çavuşoğlu ve Lamba, 2020: 144-145; Şahin, 2019: 96; Tekçe, 2018: 216; Sağırekmekçi, 2015: 119; Susta, 2018: 139). Kırsalda karşılaşılan bir diğer sorun ise mesafenin hizmet alımını belirlemesidir. Nitekim muhtarlarca ilgili belediyeye uzak olan mahallenin hizmet alımını yeterince ve gereken zamanda alamadığı, yakın olan mahallelerin ise daha avantajlı oldukları vurgulanmıştır (Sakar, 2019: 103; Aydın, 2018: 199; Tekçe, 2018:
119; Avşar, 2020: 281). Bu durum hizmet alımında adalet duygusunu zayıflatan uygulamalardır. Kırsalda yaşayan insanların yürüttükleri iktisadi faaliyetlerle ilgili veya barınma ihtiyaçları için inşa ettikleri yapıları geçmişte daha kolay yaptıkları, yasadan sonra ise sorun yaşadıkları/yaşayacakları belirtilmiştir. İmar uygulamalarının getirdiği düzenlemeyle artık ihtiyaç hâsıl olan yapıların inşasından uzak durulduğu ifade edilmektedir (Tekçe, 2018: 116; Çavuşoğlu ve Lamba, 2020: 144-145). Ayrıca, özellikle kentlere yakın yerlerdeki köyden dönüştürülen mahallelerde imar hukukuna tabi olunmasi tarımsal arazi, orman ve yayla alanlarında yapılaşmayla alan kaybının olacağı bunun da kırsalda üretimi olumsuz etkileyeceği belirtilmiş̧tir (Tekçe, 2018: 119). Çalışmalar dâhilindeki kırsal kesimde yaşayanların nerdeyse tamamı yeni düzenlemeyle gelecek/gelen yeni vergi yükümlülüklerinin olumsuz sonuçlarına işaret etmiştir. Kırsal kesimde su kullanımının tarımsal hayat için bir zaruret olduğu, dolayısıyla su faturaları ve atık su bedelleri konusunda pozitif ayrımcıllk yapılmasının istendiği belirlenmiş̧ir. Vergi ve faturalardan kaynaklı bu ve bunun gibi sorunların tarım ve hayvancılığı olumsuz etkileyerek kırdan kente göçü engelleyemeyeceği bilhassa artıracağı tespit edilmiştir (Gezgüç vd., 2016: 1682; Şahin, 2019: 95-96; Tekçe, 2018: 115, 119; Ökmen vd., 2016: 1486; Avşar, 2020: 281-282; Sağırekmekçi, 2015: 119).

Yapılan saha çalışmalarının neredeyse tamamında köylerin tüzel kişiliğinin eskisi gibi olması gerektiği yönünde görüşler bildirilmiştir (Çavuşoğlu ve Lamba, 2020: 145; Şahin, 2019: 96; Tekçe, 2018: 115, 119; Koç, 2018a: 251; Ökmen vd., 2016: 1486; Avşar, 2020: 280; Susta, 2018: 139; Ömürgönülşen vd., 2018: 200; Demirkaya ve Koç, 2017:146). Bu saha çalışmaları içerisinde özellikle Avşar tarafından yürütüleni ufuk açıcıdır. Araştırma, Türkiye'nin yedi bölgesinden, farklı siyasi partilerin yönetimde olduğu büyükşehir belediyesindeki illerde başta muhtarlar olmak üzere belediye başkanları, valive kaymakamlarla anket yöntemi yapılarak tamamlanmıştır. (Avşar, 2020). Araştırma, 159'u belediye başkanı, vali ve kaymakam, 340'1 köyden dönüştürülen mahalle muhtarı olmak üzere toplam 499 kişilik örneklem büyüklüğüyle sonuçlandırılmıştır (Avşar, 2020, 124). Bu çalışma, incelenen diğer araştırmalardan daha büyük bir örneklem büyüklüğüne, farklı coğrafi bölge ve siyasi eğilimleri olan illerde gerçekleştirildiği için anlamlı bulunmuştur. Çalışmada katılımcıların yarısından fazlası köyün kentsel bir bağlama sahip olan mahalleye dönüştürülmesini onaylamadıklarını belirtmişlerdir (Avşar, 2020, 282).

Bütün bunların sonucunda görülmektedir ki 6360 sayılı Kanun'un gerekçesi ve sunacağ 1 çözüm köyden dönüşen mahalleler ölçeğinde hâsıl olmamıştır. Bu durumda ilgili yasanın 
bazı kısımlarının yeniden gözden geçirilmesi gerekmektedir. Hem yerleşme hem de idari coğrafya bağlamıyla köyden dönüşen mahallelere eskiden olduğu gibi köy statüsüyle tüzel kişiliği yeniden verilerek köklü bir yönetim geleneğinin sürdürülmesi gerekmektedir. 6360 sayılı Yasa'nın gerekçelerinde doğrudan köyler üzerinden bir değerlendirme ve köy yönetimlerinin işlevsizliğiyle ilgili her hangi bir tespit yapılmamıştır. $\mathrm{Bu}$ bağlamda tüzel kişilikleri geri verilmek koşuluyla köyler, yasa öncesinde İl Özel İdarelerinden temin ettiği hizmet alımını mevcut durumdaki gibi ilçe belediyesi ve büyükşehir belediyelerinden almaya devam edebilirler. Bu durumda ortaya çıkabilecek yetki çatışmasında asgari ölçülerde köylerin yetkileri belediye lehine devredilerek uyuşmazlık hukuki olarak ortadan kaldırılabilir. Yasayla adı mahalleye çevrilen her köyden dönüştürülen yerleşim birimi bütün yönleriyle gerçek anlamda köy olmaya devam etmektedir. Dolayısıyla bu yerleşim birimlerinin eskiden olduğu gibi köy haline getirilmesi yönetsel yapı açısından bir gerekliliktir. Böylelikle 6360 sayılı Yasa hakkında ortaya konan itirazlar ve mağduriyet giderilmiş ve Türkiye'nin köklü yönetim geleneği muhafaza edilerek anayasanın 127. maddesinin hükmü sadece 51 ilde değil, büyükşehir belediyeli illerde de karşılık bulmuş olur.

\subsection{Kasaba ve Şehirlerin Bölümü Durumunda Olan Mahalleler}

Yerleşik hayata geçerek kentsel mekânlarda yaşamaya başlayan ilk Türk topluluklarından itibaren mahalle olgusu Türk kültürünün bir parçası durumundadır. Bu bağlamda Selçuklu Dönemi'nde de varlı̆̆g bilinen mahalle; Osmanlı Dönemi kentlerinde sorumluluk ve sosyal dayanışma içindeki bir topluluğun meskûn olduğu, çoğunlukla bağdaşık bir kültüre sahip, genellikle bir ibadethanenin çevresini saran, sosyal ve ekonomik nitelikleri bulunan kent kısımlarını tanımlamaktaydı (Erdagöz, 2012: 64-65). Başka bir ifadeyle Osmanlı'da mahalleler, idari özelliği başta olmak üzere yerel hizmetlerin üretildiği sosyokültürel ara kurumlardı. Dolayısıyla Osmanlı Dönemi'nde kent yönetimlerinin mahalleler üzerinden tanzim edildiği söylenebilir (Bulut:2001: 33; Eryılmaz ve Şen, 1994: 41; Bulut ve Akın, 2019: 46).

Muhtarlık teşkilatı kurulmadan önce dini liderler tarafından idare edilen, teşkilatlanma sağlandıktan sonra muhtarlarca yönetilen mahalle, genellikle 1000 kişi civarında bir nüfusa ev sahipliği yapan kent birimiydi. Mahalle, 1871 tarihli Osmanlı vilayet kanununda ise hane sayıları göz önüne alınarak en az elli haneden oluşan bir birim olarak tarif edilmiştir (Bayartan, 2005: 95; Kavruk, 2018: 53). Osmanlı Dönemi'nde ilk olarak 1829 y1lında oluşturulmaya başlanan muhtarlık örgütleri, 1864 tarihli Teşkil-i Vilâyet Nizamnâmesi'nde köylere denk sayılarak yerel yönetim organı olarak değerlendirilmiştir (Erdoğan, 2016:142143). 1913 yilında yürürlüğe giren İdare-i Umumiye-i Vilâyet Kanun-1 Muvakkatiyle hukuki zeminini kaybetmiş olan mahalle örgütlenmesi, görevlerine ilişkin yeni bir düzenleme oluşturulmadığından varlığını fiilen 1933 yılına kadar sürdürmüştür. Muhtarlığın fiili varlığı 1933 yılında 2295 sayılı Kanun ile sonlandırılmış; görevleri, merkezi ve belediye yönetimleri arasında paylaştırılmıştır. Aradan geçen on bir yılın ardından 1944 yılında çıarılan 4541 sayılı Şehir ve Kasabalarda Mahalle Muhtar ve İhtiyar Heyetleri Teşkiline Dair Kanun ile eskiden olduğu gibi tekrar kurulmuşlardır (Arıkboğa, 2000: 168; Palabıyık ve Atak, 2002: 337; Erdagöz, 2012: 69; Kavruk, 2018: 125). Mahalle ve idaresiyle ilgili son değişikliklerden biri 2005 yllında yürürlüğe giren 5393 sayılı Yasa ile yapılmış olup burada mahallenin tanımı yapılarak kuruluşu, kaldırılması, yönetim yapısı ve mahalleyle ilgili diğer konulara değinilmiştir. Daha sonra 2012 yılında çıkarılan Kanun ile mahallelerin sayısı artırılmıştır.

Genel olarak mahallenin yönetim yapısını oluşturan muhtar ve ihtiyar heyeti üyelerinin yetki, görev ve sorumluluklarıyla ilgili hükümler 4541 sayılı Kanun'un 3. maddesinde belirlenmiş ve mahalle yönetimlerine 5393 sayılı Belediye Kanunu gibi diğer bazı kanunlarla da ek görev tanımlaması yapılmıştır. 5393 sayılı Belediye Kanunu'nun 9. maddesinde muhtarların mahallede ikamet edenlerin gönüllü olarak katılımıyla müşterek ihtiyaçların neler olduğunu belirlemek, mahallenin yaşam niteliğini artırmak, başta belediye olmak üzere kamu kurum ve kuruluşlarıyla ilişkilerini yürüterek mahalleyi ilgilendiren konularda görüş beyan etmek ve yasalarca verilen diğer görevleri yerine getirmekle mükellef olduğu belirtilmektedir. Söz konusu madde sadece muhtarın mükellefiyetini değil aynı zamanda belediyelerin mahalleye yönelik görev ve sorumluluklarını da belirlemektedir. $\mathrm{Bu}$ kapsamda, belediyenin muhtarlık ve mahallenin gereksinimlerini karşılaması ve sorunlarını çözmek için bütçe olanaklarına göre ayni yardımı ve desteği sağlaması gerektiği belirtilmiştir. Bunun yanında belediyenin alınacak kararlarda mahallenin müşterek taleplerini önceleyerek, hizmetlerin mahallenin gereksinimlerine uygun bir şekilde yürütülmesini sağlaması gerektiği de ifade edilmiştir. Mahalle idaresinin sivil savunma, sosyal güvenlik, milli eğitim, askerlik ve avcılıkla ilgili kanunlar bağlamında yükümlülük getirilen işlerin tespit edilerek bildirilmesine yönelik kamusal hizmet görevleri bulunmaktadır. Ayrıca mahalle sakinlerinin talepleri üzerine ilgili kurumlara verilmek üzere imza, mühür, fotoğraf, kimliklerle ilgili bilgi ve belgeleri onama, seçim işleri, adliye, tebligat, vergi, ulusal savunma, seferberlik, tapu ve kadastro gibi 
birçok alanda mahalle yönetiminin görevleri bulunmaktadır (Kavruk, 2018: 140-141).

Yerel yönetimlerin yasal dayanağ1, anayasa hükümleri ve kanunlarla belirlenmiştir. Anayasanın 127. maddesine göre il özel idareleri, belediyeler ve köyler olmak üzere Türkiye'de üç adet yerel yönetim birimi bulunmaktadır. Yerel yönetimlerin yönetici üyeleri seçimle işbaşına gelmektedir. Mahalle muhtarı ve ihtiyar heyeti üyeleri de seçimle işbaşına geldikleri halde mahallenin tüzel kişiliği yoktur. Köy yönetimlerindeki gibi organları bulunduğu halde, mahalleler yerel yönetim birimi değildir. $\mathrm{Bu}$ nedenle mahalle muhtarlığının kendi bütçesi, geliri ve personeli yoktur. Mevcut haliyle mahalle muhtarlığı şehir ve kasabalardaki belediye yönetsel alanında varlık gösteren semt örgütlenmesine benzetilebilir. Ancak mahalle yönetiminin işbaşına gelme yönteminin, yükümlü olduğu bazı görevlerin merkezi idarenin yetki alanı içerisinde olmasının, mahalle ve muhtarlık kurumunun devlet tüzel kişiliği içindeki hiyerarşide en küçük yerel organ olarak değerlendirilmesi gerekliliğini ortaya koymaktadır (Güler, 2009: 298; Özçağlar, 2015: 113; Dik, 2014: 90).

Hâlihazırda yönetsel hiyerarşide yerel yönetim birimi olarak bir yeri olmasa da mahalle yönetimi, aslında kent yönetimleri açısından oldukça önemli bir birimdir. Şehirlere hizmet sunmakla yükümlü kurum ve kuruluşlarla hizmet alanlar arasındaki ilişkiler göz önünde bulundurulduğunda muhtarlığın, mahalle sakinlerinin kente ve yaşadıkları mahalleye yönelik istem ve beklentilerinin ilgililere yöneltilmesi açısından önemi büyüktür. Mahalle yönetimlerinin hizmete yönelik istem ve beklentileri belediye yönetimlerine ve/veya şehirdeki diğer ilgili birimlere taşıması, mahalle sakinlerinin yönetime katılımını sağlaması hem yerel yönetimleri hem de katılımcı demokrasiyi güçlendiren bir yoldur. Dolayısıyla kent yönetiminden sorumlu olan yapıların söz konusu kanalları açık tutacak düzenlemeleri geliştirmesiyle daha demokratik ve sürdürülebilir bir kent yaşamı sağlanabilir (Türkan, 2020: 115).

Mahalle yönetimi, Türkiye'de yerel demokrasinin gelişmesine katkı sağlayabilecek ve tabanda yönetime katılmanın en etkin araçlarından biri olabilir. Kentlerde yaşayanların en rahat erişebileceği ve onlara en yakın yönetim birimi olması sayesiyle, devlet ile vatandaş arasındaki münasebetlerin geliştirilmesinde ve kamusal hizmetlerin sürdürülmesinde mahalle yönetiminin rolü büyüktür. Bu rol fark edilmiş olmalı ki yerel kamusal hizmetlerin etkin, verimli ve güvenli bir biçimde sunulmasi; sorun, talep ve beklentilerin en kisa zamanda yetkili makamlara ulaştırılması, muhtarlığın etkinlik ve işlevselliğini artırarak taleplerinin mümkün olan en kısa zamanda neticelendirilmesi maksadıyla İçişleri Bakanlığı'nca "Muhtar Bilgi Sistemi” kurulmuştur (sbb.gov.tr, 2020: 147). Bu uygulamaya bağlı olarak da İçişleri Bakanlığı'nın 2015/8 Sayılı Genelgesi uyarınca büyükşehir belediyelerinde "Muhtarlıklar Daire Başkanlı̆̆ı", il ve ilçe belediyelerinde ise "Muhtarlıklar Müdürlüğü” adıyla birimler kurulmaya başlanmıştır (Malkara. bel.tr, 2020). Genelge uyarınca belediyelerde kurulan bu müdürlüklerin görevleri arasında muhtarlarca bildirilen mahallenin sorunlarını yerinde belirleyerek nihayete erdirilmesi hususunda ilgili birimleri aktive etmek, çözüm aşamalarının takibini yapmak ve bu süreçler kapsamında muhtarlara geri dönüş sağlamak yer almaktadır. Bunların yanında Muhtarlıklar Daire Başkanlığı/ Müdürlüklerinin bilgilendirme ve tanıtıma yönelik etkinlikler organize etmek, ayni yardım ve destekte bulunmak gibi hedefleri olduğu da görülmektedir. Ancak bu ve buna benzer düzenlemelerin palyatif çözümler olduğu, problemleri kökten çözebileceğine yönelik emareler ortaya çıarmadığı görülmektedir (Koç, 2018b: 101; Akman, 2018: 531). Köklü çözüm ise siyasi parti üyeliği olmayan, yaşadığ1 mahalle sakinleri tarafindan seçimle göreve gelerek demokratik yönetimin tabana yayılmasının en güzel örneklerinden biri durumundaki mahalle muhtarlığı ve ihtiyar heyetinin yapısal olarak güçlendirilmesiyle mümkün görünmektedir.

Yasal boyutu, görev ve yetkileriyle ele alındığında mahalle yönetimi hem yerel hem de merkezi yönetim birimi gibi görünmekte ve gündelik yaşam içerisinde buna uygun pratikler sergilemektedir. Bu anlamda faaliyetlerine bakıldığında yerel ve merkezi yönetimlerin temsilcisi ve/veya yardımcısı olan bir kuruluş gibidir. Bu bakımdan coğrafi bir mekân olan mahallenin temsil makamı durumundaki mahalle muhtarlığ 1 , merkezi ve yerel yönetimin kesişme bölgesinde faaliyet göstermektedir (Arıkboğa, 1999: 103). Bu durum hem işbaşına gelme hem de göreve başladıktan sonraki süreçte yürütülen faaliyetlerin niteliğiyle ilgilidir. Literatürde mahalle muhtarlığının konumunu merkezi yönetim içerisinde ele alan çalışmalar olduğu gibi yerel yönetimler içerisinde ele alan çalışmalara da rastlanmaktadır. Ancak 5393 sayılı Yasa hükümleri uyarınca mahalleyi ve sınırlarını belediye belirlemektedir. Dolayısıyla muhtarlığın merkezi yönetimle ilgili işlevi bulunsa da ilgili yasadan kaynaklı daha çok yerel yönetimle ilgili bir birim olarak değerlendirmek uygun olacaktır. $\mathrm{Bu}$ yasada muhtarlıkla belediye arasındaki ilişkiler birbirlerine karşı ilgi bağlamında ele alınmıştır. Ancak bu bağlam kesin hükümler düzeyinde değildir. Muhtarlık daha çok oy hakkı olmaksızın yönetime katılan, görüş bildiren, iş birliği yapan bir sivil toplum kuruluşu düzeyinde değerlendirilmektedir (Kavruk, 2018: 184). İlgili yasanın bu içeriği belediye ve mahalle muhtarlığı arasındaki ilişkide zorlayıcı bir hüküm olmadığından 
keyfiliği doğurabilmektedir. Ortaya çıkan keyfiliğin önüne geçmek ve mahalle yönetiminin işlevsel hale getirilmesinde köklü çözüm olması açısından, muhtarlığı kentsel mekânda tabandaki yerel yönetim kuruluşu olarak ihdas edip muhtarlığın tüzel kişiliğe kavuşturulması dâhil olmak üzere kapsamlı çözümler üretilmelidir. Belediyelerin idari kurullarında temsil edilmesi bakımından muhtarlığın belediye meclislerinin doğal üyesi olabilmesi, kente dair alınacak kararlar ile tasarruflarda belirleyici olması için hukuki ve idari düzenlemeler yapılmalıdır. Yerel demokrasinin işlerliği açısından katılımı önceleyecek şekilde mahalle yönetiminin alacağı kararları belirlemek adına da mahalle sakinleri arasından oluşturulacak kadın ve gençlik meclislerini barındıran mahalle meclisleri gibi yapılar oluşturulmalı ve meclislerin aldığı kararlar mahalle yönetimini bağlayıcı nitelikte olmalıdır (Erdagöz, 2012: 97).

Belirtilen önerilerin işlerliğinin oluşması belli ölçütlere göre oluşturulmuş optimal bir büyüklüğe sahip mahallelerin varlığıyla mümkündür. Ancak Türkiye'de kentin bölümleri konumundaki mahallelerin yüz ölçümü, nüfus ve mekânsal bütünlük bakımından orantısız farklılıkları bulunmaktadır. Söz konusu farklılı̆̆ı ifade etmek için seçilmiş olan örnekler Türkiye'deki tüm mahalleler içerisinde yalnızca kentsel mahallelerden ve ekstrem büyüklüğe sahip olanlardan oluşturulmuştur. Verilmiş örnekler üzerinden gidilirse İstanbul'da en küçük ve en büyük yüz ölçüme sahip olan mahalleler arasinda $31,056 \mathrm{~km}^{2}$, Kayseri'de $72,7966 \mathrm{~km}^{2}$ fark olduğu görülmektedir (Tablo 1). Tablodan da görüldüğü gibi İzmir ili Konak ilçesindeki yüz ölçümü 1 hektar bile olmayan Şehit Nedim Tuğaltay Mahallesi ile Buca ilçesi Kaynaklar Merkez Mahallesi arasındaki fark 24,5 km²'dir. Ankara, Çankırı ve Uşak'ta da benzer farklıklar olduğu tablodan anlaşılmaktadır. Bu örnekler mahalle yüz ölçümlerinin orantısızlığını ve optimal bir ölçek olması gerekliliğini yeterince izah etmektedir.

Mahalle nüfuslarında da yüz ölçümünde olduğu gibi ciddi uçurumlar bulunmaktadır. Kentin bölümleri durumundaki mahallelerin nüfus fark1 Tablo 2'deki sadece kentsel mahalleler arasından seçilmiş bazı örnekler üzerinden değerlendirildiğinde hem kent içi hem de kentler arasında çok büyüktür. Nitekim Diyarbakır'da mahalleler arasında 127.442, İstanbul'da 98.795, Bursa'da 48.898 ve Karaman'da 8.224 kişilik nüfus farkı bulunmaktadır. Türkiye'de nüfusu en fazla olan mahalle 127.839 kişi ile Diyarbakır ili, Bağlar ilçesi, Bağcılar Mahallesidir. Nüfusu en az olan ise 11 kişi ile Bursa ili, Nilüfer ilçesi, Minareliçavuş

Tablo 1. Seçilmiş mahallelerin yüz ölçümleri.

Table 1. Area of the selected neighborhoods.

\begin{tabular}{|c|c|c|c|c|}
\hline il & illçe & Mahalle & Yüz ölçüm (km²) & Fark $\left(\mathbf{k m}^{2}\right)$ \\
\hline İstanbul & Fatih & Tahtakale & 0,047 & \\
\hline İstanbul & Pendik & Kurna & 31,103 & 31,056 \\
\hline Kayseri & Hacılar & Orta & 0,052 & \\
\hline Kayseri & Melikgazi & Hisarcık & 72,8486 & 72,7966 \\
\hline Ankara & Çankaya & Topraklık & 0,06 & \\
\hline Ankara & Çankaya & Beytepe & 26,541 & 26,481 \\
\hline İzmir & Konak & Şehit Nedim Tuğaltay & 0.00951 & \\
\hline İzmir & Buca & Kaynaklar Merkez & 24,6 & 24,59049 \\
\hline Çankırı & Merkez & Tabakhane & 0,05 & \\
\hline Çankırı & Merkez & Fatih & 8,61 & 8,56 \\
\hline Ușak & Merkez & Özdemir & 0,051 & \\
\hline Ușak & Merkez & Fatih & 8,813 & 8,762 \\
\hline
\end{tabular}

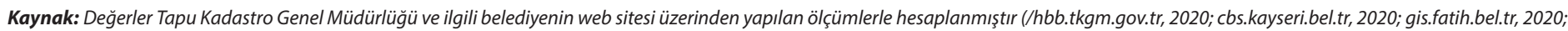
cbs.pendik.bel.tr, 2020; cbs.cankaya.bel.tr, 2020; kentrehberi.izmir.bel.tr, 2020).

Tablo 2. Seçilmiş Mahallelerin Nüfus Miktarları.

Table 2. Populations of selected neighborhoods.

\begin{tabular}{lllll}
\hline İ Adı & İlçe Adı & Mahalle Adı & Toplam Nüfus & Nüfus farkı \\
\hline Diyarbakır & Bağlar & Bağcılar & 127.839 & 127.442 \\
Diyarbakır & Sur & Süleyman Nazif & 397 & 98.807 \\
İstanbul & Küçükçekmece & Atakent & 12 & 98.795 \\
İstanbul & Fatih & Sarıdemir & 48.909 & \\
Bursa & Osmangazi & Hamitler & 11 & \\
Bursa & Nilüfer & Minareliçavuş Osb & 8.235 & 48.898 \\
Karaman & Merkez & Gevher Hatun & 11 & 8.224 \\
Karaman & Merkez & Organize Sanayii Bölgesi & \\
\hline
\end{tabular}

Kaynak: Tüik 2019 verileri (biruni.tuik.gov.tr, 2020). 
Osb Mahallesi ile Karaman ili, merkez ilçesi, Gevher Hatun Mahallesidir. Nüfusu 11 kişi olduğu halde veri kalabalıklığı yaratmamak için İzmir ve Malatya'daki mahalleler tabloya dâhil edilmemiş, problemi izah etmek için Tablo 2'deki veriler yeterli bulunmuştur. Görüldüğü gibi Türkiye'de kentsel mahalleler arasında 127.828 kişilik bir fark bulunmaktadır. Bağcılar ile Atakent Mahallesi mevcut nüfus miktarıyla hâlihazırda il merkezi olan ve büyükşehir belediyesi bulunan birçok şehirden daha kalabalıktır. Hatta bu iki mahallenin ayrı ayrı nüfus miktarları Ardahan, Bayburt ve Tunceli illerinin toplam nüfusundan da fazladır. Konu idari yönü üzerinden değerlendirildiğinde Bağcılar Mahallesi ile Gevher Hatun Mahallesi aynı makamla yani muhtarlık birimi ile temsil edilmektedir. Bu bağlamda Türkiye'de mahalle sınırlarının belirli parametrelerle yeniden belirlenmesi ihtiyac1 belirmektedir. Nitekim mevcut durumun temsilde hakkaniyete uygun olduğu söylenemez.

Türkiye'de mahallelerin büyük bir kısmında yapılar toplu halde bulunurken bir kısmında dağınık durumdadır. Bu bakımdan bazı mahallelerde mekânsal bir bütünlük bulunduğunu söylemek güçtür. Mahalledeki mekânsal bütünlük mahalleyi oluşturan yapıların birbirleriyle olan mesafesine bağlıdır. Mahalleyi oluşturan yapılar arasında fazla bir mesafe bulunmamalıdır. Ancak ülkedeki bazı mahallelerin içerisinde gerek beşeri gerekse de doğal eşikler bulunmaktadır. Bu eşikler mahallenin mekânsal bütünlüğünü ihlal etmektedir. Esasen söz konusu boşluklar mahallenin içerisinde yer almamalı, bir mahalleyi diğerinden ayırmak için kullanılması gereken doğal veya beşeri sınırlar olmalıdırlar. Mahalleler içerisindeki boşluklar aynı sınırlar içerisinde yaşayan sakinlerin zihninde bütünlüğü ortadan kaldırdığı için mahalleyle ilintili aidiyet duygusunun gelişmesi mümkün olmamaktadır. Bu durum mahalle sakinlerinin mahalle sorunlarını algılaması, mekânsal sorunların tespiti ve çözümü bağlamında oluşturabilecekleri ortak bağı engelleyebilir. Bu çerçevede mahallelerin mekânsal bütünlüğe sahip olması, bulunmuyorsa da oluşturulması gerekmektedir.

\section{KENTSEL MAHALLELERDE OPTIMMAL ÖLÇEK VE SINIR}

Türkiye'deki mahallelerin optimal büyüklüğünün belirlenmesinde üç temel ölçütün dikkate alınması gerekmektedir (Türkan, 2020: 123). Bu ölçütler şunlardır:

1. Nüfus

2. Yüz ölçümü

3. Mekânsal bütünlük

a. Doğal eşikler

b. Beşeri eşikler
5393 sayılı Belediye Yasası'nda mahallenin tanımı yapılmış ve belediye sınırları dâhilinde yeni bir mahalle kurulacağı zaman nüfus bakımından alt sınırın ne olduğu belirlenmiştir. İlgili yasada yeni bir mahalle kurulmasında nüfusunun 500 kişinin altında bulunmayacağı belirlenmiș ancak üst sınıra yönelik bir hüküm yer almamıştır. Haliyle bu durum mahallelerde nüfus açısından bir optimal ölçek sorunu ortaya çıkarmaktadır. Belediyenin tanımı ve görevlerinin belirlendiği 5393 sayılı Kanununun 4. maddesinde belediye kurulması için gereken asgari nüfus miktarının 5.000 kişi olduğu ifade edilmektedir. Buradan hareketle önceki bölümde muhtarlığın yasal zemininin güçlendirilip yetkileri artırılarak belediyenin bir alt örgütlenmesi yerine geçmesi önerisi temel alındığında, ilgili kanuna atfen mahalle nüfusunun en düşük belediye nüfusu olan 5.000 kişiye eşitlenmesi gerekir. Çünkü öneri doğrultusunda mahalleler kentlerin en küçük yerel yönetim birimi olacağından nüfusunun da asgari belediye nüfusu olması uygun olacaktır. Nitekim mahalle yönetiminin sorunları ve çözümlerine yönelik muhtarlarla yapılan kapsamlı bir çalışmada mahalle nüfusunun en çok 5.000 kişi olması önerisi yüksek oranda desteklenmiştir. Söz konusu çalışma Kalkınma Bakanlığı bünyesinde farklı bölgelerden muhtarlardan oluşan 3147 kişiyle anket yöntemiyle yapılmış olup muhtarların \%62,8'i mahalle nüfusunun 5.000 kişiyi geçmemesi gerektiğini ifade etmiştir (Bilgin vd., 2018: 107-108). Bu bağlamda optimal nüfus ölçütünün temelde 5.000 olmak üzere,+-1.000 kişi aralı̆̆ında olması uygundur. Mahalle sınırlarında değişime gidileceği zaman ise mahallenin son beş veya on yıllık zaman dilimi içerisindeki nüfus artış seyrine bakılması gerekir. Mahalle nüfusunun 4.000 - 6.000 kişi bandındaki miktarı artan veya azalan bir seyir gösteriyorsa mahallenin bölünmesi veya bir diğeriyle birleştirilmesi gerekir. 5.000 kişilik optimal nüfus miktarı önerisi sadece ilgili yasa maddesine atıfta bulunmamaktadır. Mahalle kimliği ve aidiyetinin oluşabilmesi için mahalle sakinlerinin birbirlerini tanımaları, hiç değilse birbirlerine aşina olmaları gerekir. Mahalle sakinlerinin yaşadıkları yer ile ilgili sorunları algılaması, tespit etmesi ve çözme iradesini ortaya koymada aidiyet duygusundan beslenmesi gerekir. $\mathrm{Bu}$ ise insanın gündelik yaşamında görüp tanıyabileceği veya anımsayabileceği sima adedine göre oluşabilecek bir durum olup bu sayı da yaklaşı 5.000 kişi civarındadır. Dolayısıyla 5.000 kişi aynı mahallede yaşayan, benzeşik gereksinim ve öncelikleri olan, sakinleri arasında komşuluk ilişkisi bulunan bireylerin yüz yüze ilişki kurabilme ve ilişkilerini geliştirerek mahallelilik bilincini sağlamlaştırabilir (Çetiner, 1972: 36; Erkan, 2019: 57). Türkiye'de 5.000 nüfusun altında 527 belde veya ilçe belediyesi bulunmaktadır. Mahalle muhtarlığının işlevselliği için belirlenen 5.000 kişilik optimal nüfusun altında kalan bu tür yerleşmelerde 
mahalle kurulmasına gerek yoktur. Çünkü bu yerlerde hizmet beklentisinde olan birey sayısı az olduğundan belediyeler hem muhtarlığın yürüttüğü işleri hem de kendi görev ve sorumluluklarınıyerine getirmekte fazlasorunyaşamayacaklardır.

Mahallenin yüz ölçümünü belirlemede kullanılan temel unsur bireyin yaya olarak yorulmadan yürüyebildiği mesafedir. Yüz ölçümü için belirlenen ölçüt mahalle sakinlerinin mahalle içerisinde günlük maddi ve sosyokültürel ihtiyaçlarını karşılamak durumunda olduğunda yürünebilecek mesafeyi vermektedir. Söz konusu mesafe mahalle sakininin toplu taşıma araçlarına ulaşma, okul, sağlık ocağı, alışveriş mekânları, ibadethane, park ve spor alanları gibi rekreasyon alanlarına erişmede yorgunluk hissettirmeyecek ölçüde olmalıdır. Yetişkin bir bireyin mahallenin topografyasında yürümeyi güç kılan kısıtlarının bulunmadığı durumlarda yürüyebildiği mesafe ortalama olarak $800 \mathrm{~m}$ civarındadır. Bu değerden yola çıkıldığında mahalle büyüklüğü istisnai haller dışında 50 hektardan fazla 20 hektardan da az olmamalıdır (Bakan ve Konuk, 1987: 20; Erkan, 2019: 56-57).

Türkiye'de optimal mahalle büyüklüğünün belirlenmesinde dikkat edilmesi gereken bir diğer ölçüt mahallenin mekânsal bütünlük oluşturup oluşturmamasıdır. Mahalleyi oluşturan konutlar, sosyokültürel ve diğer yapılar birbirlerinden kopuk bir biçimde lokalize olmamalıdır. Yani mahalleyi oluşturan her türlü beşeri yapının aralarındaki mesafenin az olması hatta neredeyse bitişik nizamda bulunması gerekmektedir. Mahallelerdeki mekânsal bütünlük doğal ve beşeri olmak üzere çok çeşitli unsurlar tarafından bozulmuş durumdadır. Dolayısıyla mevcut mahallede veya oluşturulacak yeni bir mahalle içerisinde doğal ya da beşeri eşiklerin belirgin olmaması gerekir. Bu kısımda konu doğal ve beşeri eşiklerin tümü yerine belli başlıcalarını yansitan mahalleler üzerinden verilecektir.

Kentler içerisinde görülebilecek doğal eşikler; tepe, sirt, vadi, kayalıklar, orman, çalılık alanlar ve akarsu gibi unsurlardır. $\mathrm{Bu}$ unsurlar dikkate alınmadan mahalle sınırları bu doğal birimleri çevreleyecek şekilde çizilmemelidir. Mahallede mekânsal bütünlüğü engelleyen doğal unsurlardan biri akarsulardır. Normal şartlarda akarsular mahalle sınırı tespitinde istifade edilecek doğal bir sınır iken bazı mahallelerde akarsular mahallenin içinden geçmektedir. Örneğin Ankara ili Etimesgut ilçesi Etiler Mahallesi içerisinden Ankara Çayı geçmektedir (Şekil 5). Şekilden de açıkça görüldüğü gibi Ankara Çayı mahalleyi ikiye bölerek mahallenin mekânsal bütünlüğünü engellemektedir. Sonuç olarak Ankara Çayı doğal sınır olmak üzere mahallenin bölünmesi gerekmektedir.

Şehirlerin kurulduğu yerler, morfolojik açıdan düzlüklerin geniş alanlar kapladığı bir bölge olmayabilir. Yedi tepeli kent olarak anılan İstanbul gibi kentlerde tepeler mahallelerin mekânsal bütünlüğünü bozan önemli doğal unsurlardandır. Benzer örnek olarak Ankara ili, Mamak ilçesi Kutlu Mahallesi bir tepe üzerinde yer alır. Nitekim Mahalle haritasından alınan A-B profilinden de görüldüğü üzere mahalle içerisinde bir tepe ve yamaçlar bulunmaktadır (Şekil 6). Dolayısıyla B noktasının bulunduğu kesimden profil hattının orta ve kuzey kesimleri görünmemektedir. Morfolojisi böyle olan bir bölgede mahallenin mekânsal bütünlügü bulunmadığından mahallelilik bilincinin gelişmesi beklenemez. $\mathrm{Bu}$ tür tepelik bölgelerde mahalle

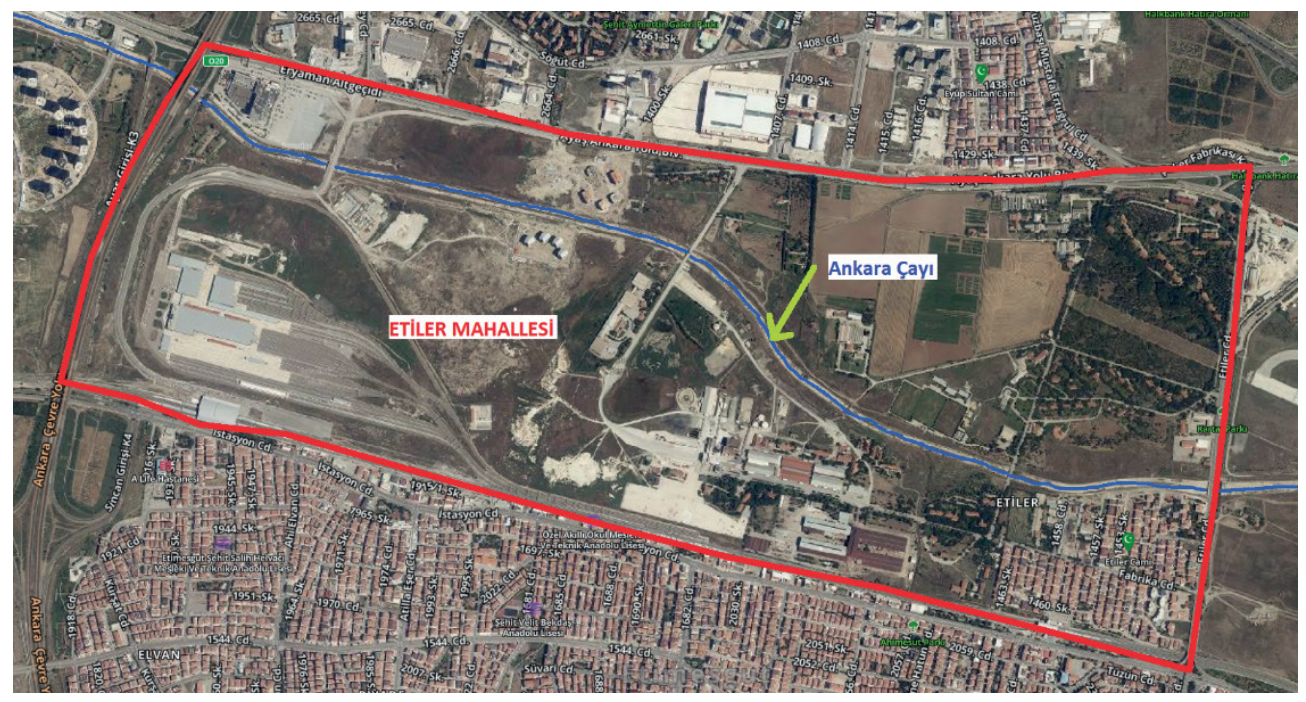

Şekil 5. Ankara İli, Etimesgut İlçesi Etiler Mahallesi.

Figure 5. Etiler neighborhood (Etimesgut/Ankara).

Kaynak: http://socbs.etimesgut.bel.tr:8080/EKentRehberi/ (26.12.2020). 


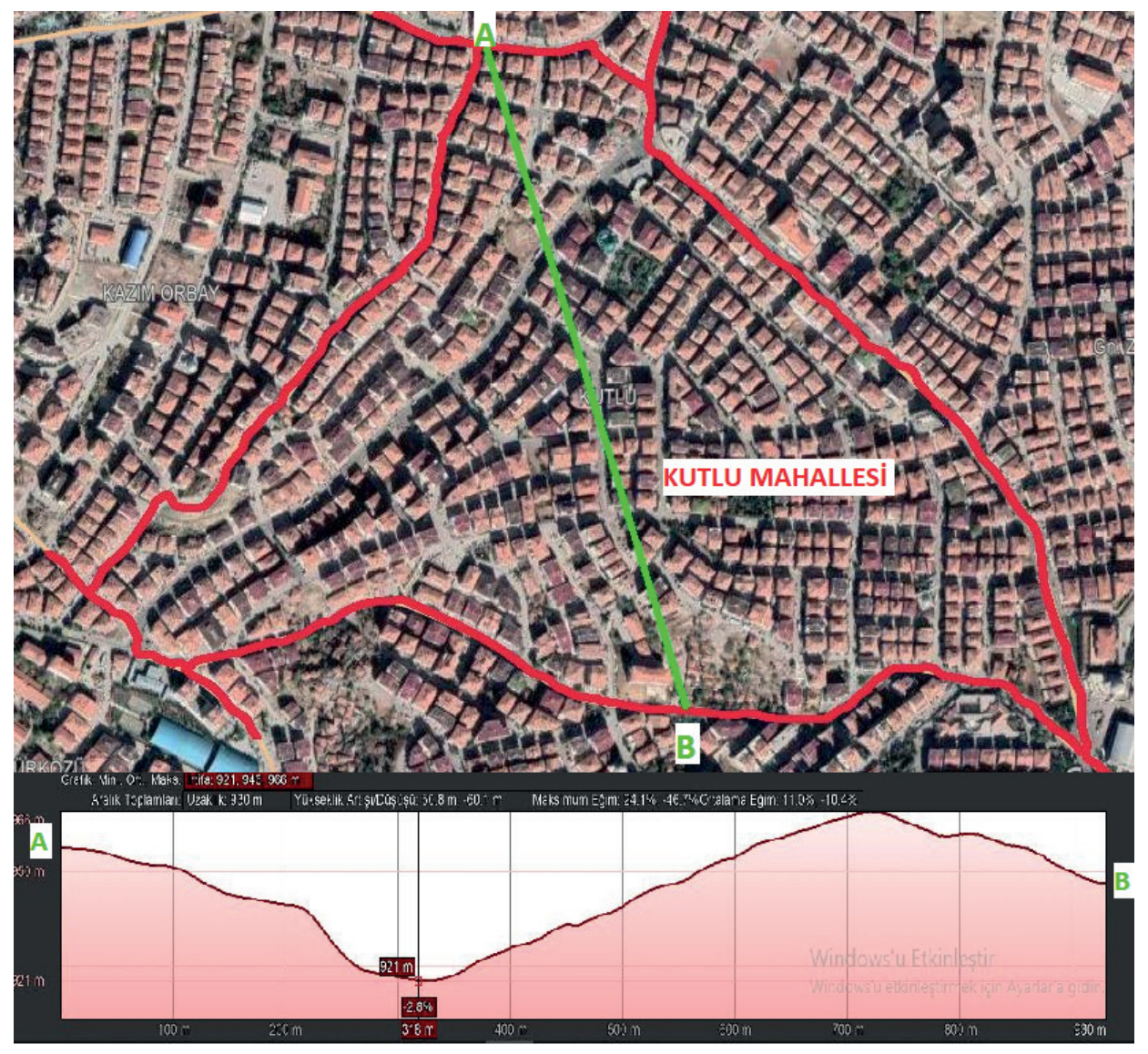

Şekil 6. Ankara İli, Mamak İlçesi Kutlu Mahallesi.

Figure 6. Kutlu neighborhood (Mamak/Ankara).

Kaynak: https://ims.mamak.bel.tr/Projects/MAMAK/Pages/KRH.aspx (26.12.2020).

sınırlarının tepeyi mahalle içerisinde bırakacak biçimde değil, tepenin zirve kısımlarından yani yerel su bölümü çizgisinden geçirilerek çizilmesi gerekmektedir.

Mevcut mahallede veya yeni kurulacak bir mahallede belirgin bir beşeri eşik bulunmaması gerekir. Kentler içerisinde görülebilecek olan beşeri eşikler; sanayi alanları, otoyol, demiryolu, bulvar ve geniş caddeler, geniş alan kaplayan rekreasyon, eğitim, ticaret, sosyokültürel ve sağlık alanları gibi büyük donatı alanlarıdır. Bu eşikler göz önünde bulundurularak mahalle sınırları çizilmelidir. Örneğin Ankara ili, Yenimahalle ilçesi Yenibatı Mahallesinin konumuna bakıldığında mahallenin mekânsal bütünlüğünün hem doğal hem de beşeri unsurlar tarafından bozulmuş olduğu görülür (Şekil 7). Mahallenin doğu ve batı kesimi arasında yükselti ortalaması $50 \mathrm{~m}$ civarında olan tepeler bulunduğu gibi mahallenin orta kesiminde hipodrom, Atatürk Orman Çiftliği arazisi, 75. Yıl Maliye Ormanı, Türkiye Elektrik İletim Anonim Şirketi trafosu, TRT vericisi ve yüzeye çıkmış olan metro hattı yer almaktadır. Söz konusu bu mahallenin ortasındaki doğal ve beşeri eşikler sınır olacak şekilde, doğu ve batısında ayrı mahallelerin oluşturulması gerekir. Ayrıca, mahallenin doğu kesiminde Yıldırım Beyazıt Üniversitesi Yenimahalle Eğitim ve Araştırma Hastanesi ve caddeler yer almaktadır. Bu eşiklere göre mahallenin doğu kesiminin de bölünmesi gerekmektedir. Nitekim 2019 yılı itibarıyla mahalle nüfusunun 27.690 kişi olması da bu bölünmeleri kolaylaştıracaktır.

Ankara ili, Mamak ilçesi Demirlibahçe Mahallesi sınırları içerisinden çift hat elektrikli demir yolu hattı geçmektedir (Şekil 8). Bu mahalle bu haliyle mekânsal bütünlüğe sahip değildir. Demiryolunun batısında yaşayan insanlar ile doğusunda yaşayanların ortaklaşa kullandığı mekânlar fazla değildir. Aslında burada iki ayrı mahalle bulunmaktadır. Dolayısıyla Demirlibahçe Mahallesinin demiryolu sınır olmak üzere iki ayrı mahalle haline getirilmesi gerekmektedir.

Sonuç olarak optimal mahalle büyüklügünün belirlenmesinde nüfus miktarı, yüz ölçüm ve mekânsal bütünlük temel ölçütler olmalı ve bu ölçütlerin mevcut veya yeni oluşturulacak mahallelerin sınırlarının tespitinde baz alınması gerekmektedir. 


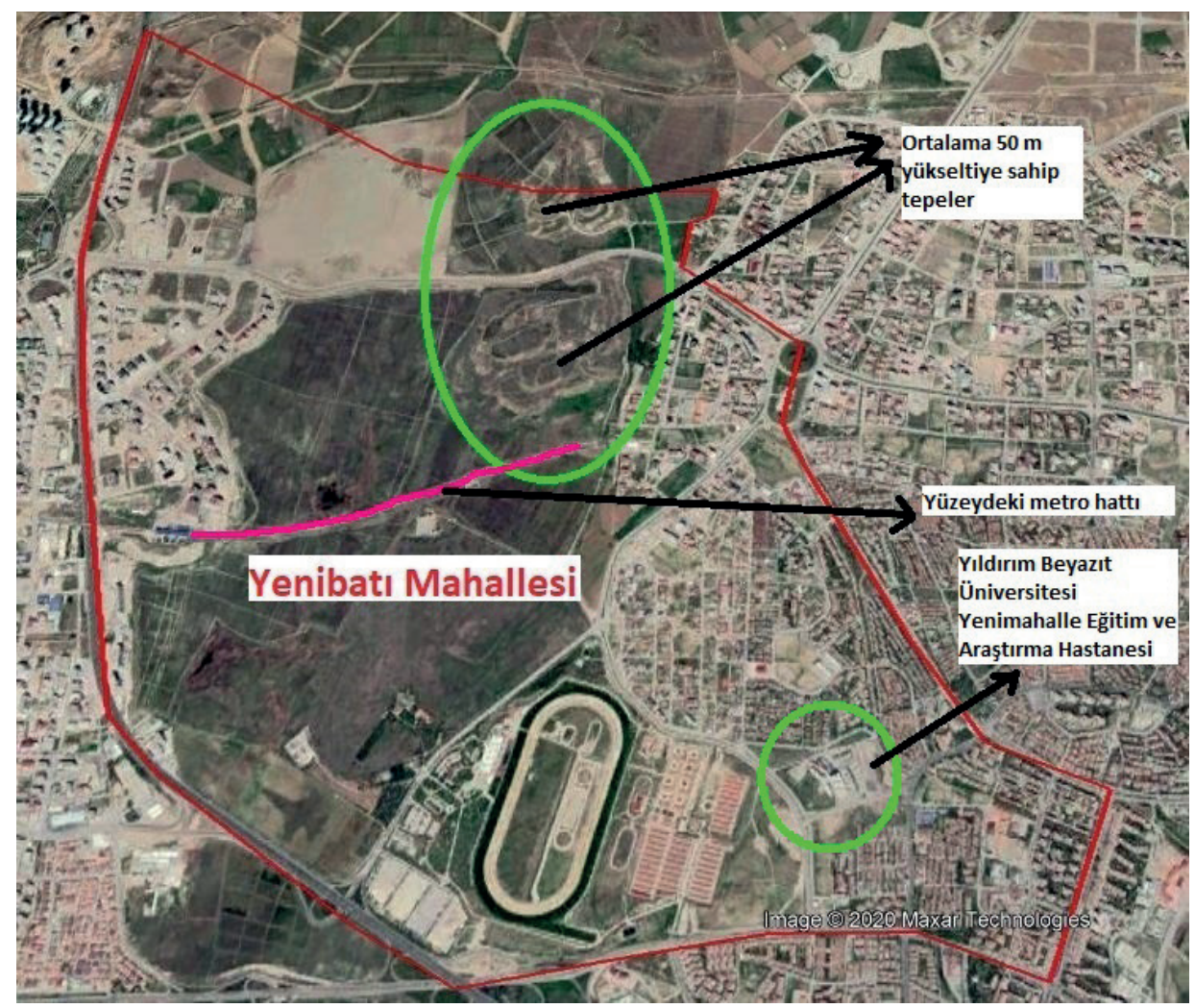

Şekil 7. Ankara İli, Yenimahalle İlçesi Yenibatı Mahallesi.

Figure 7. Yenibatı neighborhood (Yenimahalle /Ankara).

Kaynak: https://ekentrehberi.yenimahalle.bel.tr:81/KentrehberiApp/Index\# (26.12.2020).

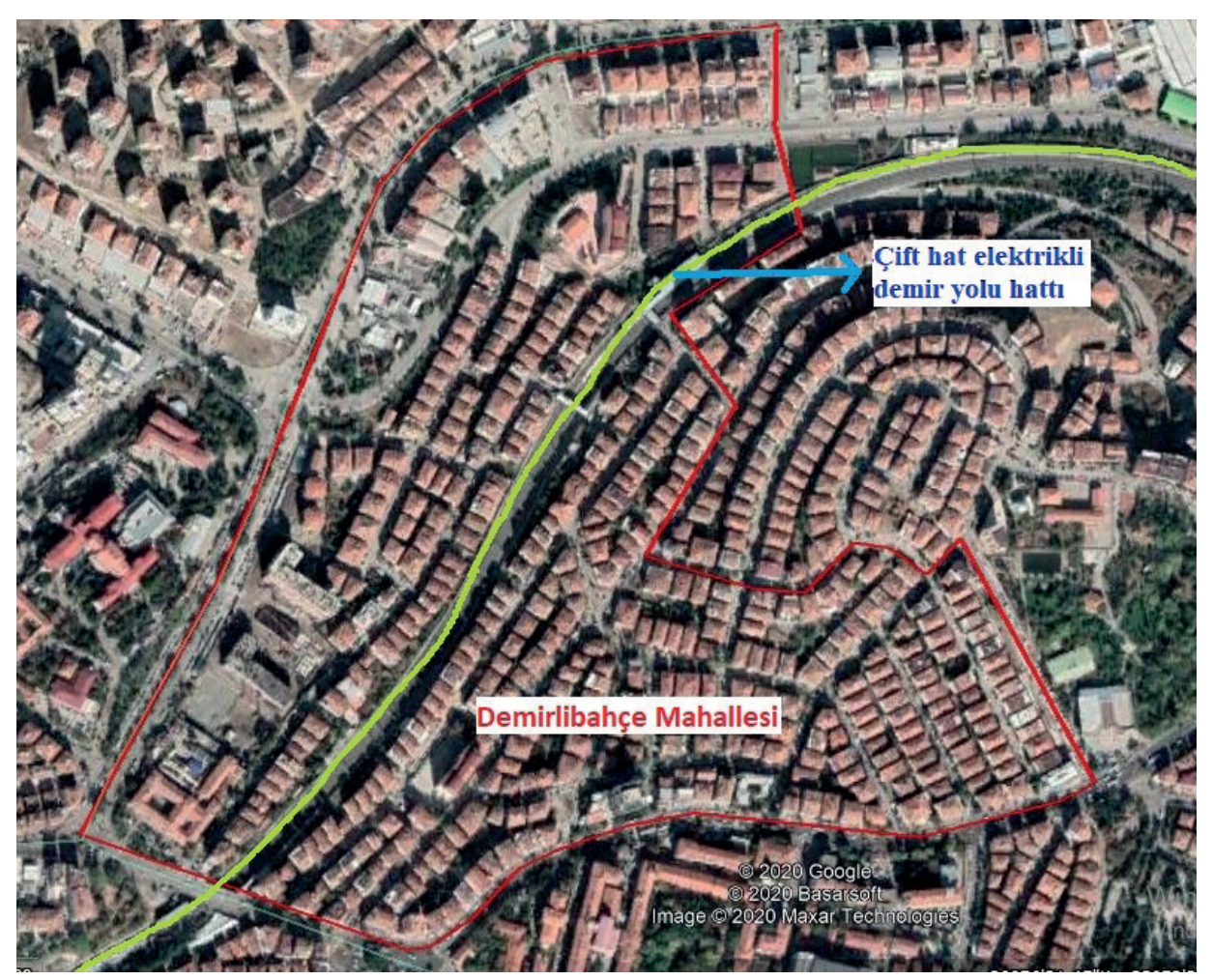

Şekil 8. Ankara İli, Mamak İlçesi Demirlibahçe Mahallesi.

Figure 8. Demirlibahçe neighborhood (Mamak/Ankara).

Kaynak: https://ims.mamak.bel.tr/Projects/MAMAK/Pages/KRH.aspx (26.12.2020). 
Ancak belirtilen ölçütlerin değişmez bir biçimde her yerde aynı şekilde uygulanabilirliği söz konusu olmadığında gerekli hallerde ölçütlerde esnemeye gidilmelidir. Mahalle sınırlarının tespitinde tüm kriterlerin karşılanmaması durumunda doğal ve beşeri eşikler dikkate alınmak şartıyla bu ölçütlerden hangisi belirlenen kriteri karşıllyorsa ona göre sınır oluşturulmalıdır. Örneğin sırf nüfus kriterini sağlamak için mahalle yüz ölçümü ölçeğinin aşılmaması gerekir. Nüfus ölçeğini gerçekleştirmek için bu durumun dikkate alınmaması alansal büyüklüğü atlamak anlamına gelecektir. Mekânsal bütünlük göz önüne alınmak şartıyla yüz ölçümüne uygun bir sınır tespiti yapılırken mahallenin nüfus konusunda esnek olunabilir. Çünkü bazı mahallelerde evler tek katlı ve bahçeli olup dağınık düzende bulunabilmektedir. Bu durumda yüz ölçümü kriteri karşılanmışsa nüfusa bakılmamalıdır. Tersine bir durumda ise çok katlı binaların bulunduğu bölgelerde sırf yüz ölçümü ölçeğinin karşılanması nüfus kriterini atlamak anlamına gelecektir. Böyle yerlerde mahalle sınırları belirlenirken yüz ölçümü eşik değerinin altında olsa da nüfusa bakılmalıdır. Ayrıca yüz ölçümü veya nüfus ölçeğini karşılamak için mahalleyi bölen doğal veya beşeri eşikleri oluşabilecek mahalleler oluşturulmamalıdır. $\mathrm{Bu}$ tür doğal veya beşeri eşikler ancak mahallenin sınır hattını oluşturabilir. Dolayısıyla doğal ve beşeri eşikler dikkate alınarak nüfus, yüz ölçümü ve mekânsal bütünlükten hangisi karşılanıyorsa mahalle sınırlarının revize edilmesinde bazı esneklikler olabilir.

\section{SONUÇ VE DEĞERLENDIRME}

Türkiye'de mahalle, hem kırsal hem de kentsel yerleşmelerde karşılaşılan bir kavramdır. Mahalle kavramını barındıran çalışmalarda hem yerleşme hem de idari coğrafya bağlamında üç farklı mahalle ile karşılaşılmaktadır. Bunlar; büyükşshir belediyesi bulunmayan illerdeki çok yerleşmeli köy idari alanlarındaki mahalleler, diğeri büyükşehir belediyeli illerdeki köylerin tüzel kişiliği kaldırılarak oluşturulan mahalleler ile bunlara bağlı durumdaki mahalleler ve son olarak da kasaba ve şehirlerin bölümleri durumundaki mahallelerdir. Birbirlerinden farklı bu yerleşmelerin ortak noktası adında mahalle bulunmasıdır. Yerleşme ve yönetsel coğrafyada karşılığı bulunan ve karışıklıklar barındıran bu kavramın netlik kazanması gerekmektedir.

\section{Yerleşme coğrafyası kapsamında;}

- Büyükşsehir belediyesi bulunmayan illerdeki çok yerleşmeli köy idari alanlarındaki mahalleler ile büyükşehir belediyeli illerdeki köyden dönüştürülen mahallelere bağlı durumdaki mahallelere kırsal mahalle,
- Kentin bölümleri durumundaki mahalleler kentsel mahalle,

- Büyükşsehir belediyeli illerdeki köylerin tüzel kişiliği kaldırılarak oluşturulan mahalleler ise 6360 sayılı Yasa öncesinde olduğu gibi köy olarak adlandırılmalıdır.

\section{İdari coğrafya kapsamında;}

- Büyükşehir belediyesi bulunmayan illerdeki çok yerleşmeli köy idari alanlarındaki mahalleler ile büyükşsehir belediyeli illerdeki köyden dönüştürülen mahallelere bağlı durumdaki mahallelerin idari hiyerarşide statü gereksinimi yoktur,

- Büyükşsehir belediyeli illerdeki köyden dönüştürülen mahallelerin eskiden olduğu gibi köye dönüştürülmesi ve geri kalan 51 ildeki köyler gibi tüzel kişilikleri verilerek bu yerleşmelerin aslına rücu etmesi gerekir.

- Kentlerin bölümleri durumundaki mahalleleri kentsel yerleşmelerde tabandaki yerel yönetim birimi olarak ihdas etmeli ve bunlara tüzel kişilik verilmelidir. Kentsel mahalle muhtarlığı için belediyelerin çeşitli birimlerinde kentle ilgili söz, yetki ve karar vermesini sağlayacak hukuki ve idari düzenlemelere gidilmesi gerekir.

$\mathrm{Bu}$ önerilerin gerçekleşmesi durumunda mevcut mahallelerde veya yeni bir mahalle kurulması durumunda optimal ölçek sorununun çözülmesi gerekecektir. Türkiye'deki mahallelerin optimal büyüklüğünün belirlenmesinde üç temel ölçütün dikkate alınması gerekmekte olup bunlar;
1. Nüfus
2. Yüz ölçümü
3. Mekânsal bütünlük
a. Doğal eşikler
b. Beşeri eşiklerdir.

- Optimal nüfus ölçütünün temelde 5.000 olmak üzere +,-1.000 kişi aralığında olması, mahalle sınırlarında değişime gidileceği zaman mahallenin son beş veya on yıllık zaman dilimi içerisindeki nüfus artış seyrine bakılması gerekir.

- Mahallenin yüz ölçümünü belirlemede kullanılan temel unsur bireyin yaya olarak yorulmadan yürüyebildiği mesafe olup mahalle büyüklüğü istisnai haller dışında 50 hektardan fazla 20 hektardan da az olmamalıdır.

- Türkiye'deki mahallelerin mekânsal bütünlügü doğal ve beşeri olmak üzere çok çeşitli eşikler tarafından bozulmuş durumdadır. Mahalle büyüklüğünün belirlenmesinde 
mekânsal bütünlük aranmalıdır. Mahalle içerisinde kopukluk yaratacak biçimde doğal veya beşeri belirgin eşiklerin bulunmaması gerekir. Bu eşikler mahallelerin ancak sınırları olmalıdır.

Hasılı optimal mahalle büyüklüğ̈nün belirlenmesinde doğal ve yapay eşikler dikkate alınarak nüfus, yüz ölçümü ve mekânsal bütünlük ölçütlerinden hangisi karşılanıyorsa ve cüzi esneklikler yapılabilmesi kaydıyla mahalle sınırlarının yeniden düzenlenmesi gerekmektedir.

Hakem Değerlendirmesi: Dış bağımsız.

Çıkar Çatışması: Yazar çıkar çatışması bildirmemiştir.

Finansal Destek: Yazar bu çalışma için finansal destek almadığını beyan etmiştir.

Peer-review: Externally peer-reviewed.

Conflict of Interest: The author has no conflict of interest to declare.

Grant Support: The author declared that this study has received no financial support

\section{KAYNAKÇA/REFERENCES}

Akman, Ç. (2018). Mahalle yönetimi ile ilgili yeni bir yasal düzenleme gerekli mi? Isparta ili özelinde bir araştırma. Akademik Araştırmalar ve Çalışmalar Dergisi, 10(19), 516-534.

Alada, A. (1989). Osmanlı Türk şehrinde mahalle. (Doktora Tezi). Ankara Üniversitesi Sosyal Bilimler Enstitüsü, Ankara.

Alver, K. (2013). Mahalle-mahallenin toplumsal ve mekânsal portresi. Ankara: Hece Yayınları.

Arıkboğa, E. (1999). Yerel yönetim açısından mahalle muhtarlığına bir bakış. Çă̆daş Yerel Yönetimler, 8(3), 103-125.

Arıkboğa, E. (2000). Boşluk doldurucu ve aracı kurum: mahalle muhtarlığı. Yerel Yönetimler Sempozyumu Bildirileri. (Ed. B. A. Güler ve A. Sabuktay). Ankara: TODAİE YYAEM Yayınları, 167176.

Avşar, Y. (2020). Türkiye'de 6360 sayıl yasa kapsamında mahalle ve köy yönetiminde yaşanan değişim ve dönüşüm. (Doktora Tezi). Kahramanmaraş Sütçü İmam Üniversitesi Sosyal Bilimler Enstitüsü, Kahramanmaraş.

Aydın, F. (2018). 6360 sayılı kanun kapsamında mahalleye dönüşen köyler: yapısal ve işlevsel açıdan bir inceleme (Manisa örneği). (Yüksek Lisans Tezi). Süleyman Demirel Üniversitesi Sosyal Bilimler Enstitüsü, Isparta.

Aytaç, F. (1995). Mahalle muhtarının el kitabı. Ankara: Seçkin Yayınevi.

Bakan, K. ve Konuk, G. (1987). Türkiye'de kentsel dış mekânların düzenlenmesi. Ankara: Tübitak Yayınları No: 45.

Bayar, R. ve Karabacak, K. (2020). Başkentin merkezinde köy kalmak: Çankaya ilçesinin (Ankara) kırsal mahalleleri. Ege Coğrafya Dergisi, 29(1), 87-106.

Bayartan, M. (2005). Osmanlı şehrinde bir idari birim: mahalle. Coğrafya Dergisi, (13), s. 93-107.
Bekdemir, Ü., Kocaman, S. ve Polat, S. (2014). Yeni büyükşehir yasası sonrasında Türkiye'de şehir nüfusu ve şehir yerleşmeleri. Doğu Coğrafya Dergisi, 19(32), 277-297.

Bilgin, K. U., Gündüzöz, İ. ve Urhan, V. F. (2018). Yeni büyükşehir belediye yasaları öncesinde Türkiye'de mahalle yönetimi araştırması 2012. Türkiye'de mahalle yönetimi araştırmaları. (Ed. K. U. Bilgin ve İ. Gündüzöz). Ankara: T.C. İçişleri Bakanlığg, (Klasmat Matbaacilık), 61-122.

Bulut, Y. (2001). Mahalle muhtarlığı üzerine bir araştırma. Çağdaş Yerel Yönetimler Dergisi, 10(3), 32-51.

Bulut, Y. ve Akın, S. (2019). Katılımcı demokrasi açısından mahalle yönetiminin önemi. Mahalle odaklı katılım. (Ed. Özservet, Ç., Y. ve H. Küçük). Ankara: Astana Yayıncılık, 45-53 .

Çalcalı, Ö. (2014). 6360 Sayılı Kanun'un Türkiye'de yerel yönetimler sistemine getireceği değişiklikler. Çă̆daş Yerel Yönetimler, 23(4), 49-68.

Çavuşoğlu, A. ve Lamba, M. (2020). 6360 Sayılı Kanun'un mahalleye dönüşen birimler üzerine etkisi: Antalya ili örneği. Bartın Üniversitesi İktisadi ve İdari Bilimler Fakültesi Dergisi, 11(21), 123-147.

Çetin, Ö., Yılmaz, Z. N. ve Erdem, H. (2016). Büyükşehir belediyeleri mali sisteminin gelişimi ve 6360 sayılı yasanın gelişime etkileri: TR32 illeri örneği. Yönetim ve Ekonomi Araştırmaları Dergisi, 14(4), 168-197.

Çetiner, A. (1972). Şehircilik çalışmalarında donatım ilkeleri. İstanbul: İTÜ Mimarlık Fakültesi Yayını.

Çolak, Ç. D., Sağlam, H. ve Topal, A. (2017). 'Bütünşehir' modelinin 2014 büyükşehir belediye başkanlığı seçimlerine etkileri. Çăgdaş Yerel Yönetimler Dergisi, 26(2), 1-47.

Çopuroğlu, M. A. (2017). Büyükşehir belediye sınırları içinde yer alan kırsal yerleşmelerin sorunları üzerine bir değerlendirme. Süleyman Demirel Üniversitesi Mimarlık Bilimleri ve Uygulamaları Dergisi, MBUD, 2(2), 18-32.

Demirkaya, Y. ve Koç, M. (2017). 6360 sayılı kanun ile birlikte mahalleye dönüşen köylerde değişimin katılım açısından muhtarlığa etkisi: Menteşe ve Seydikemer ilçeleri üzerinden bir değerlendirme. Strategic Public Management Journal, 3(6), 124-149.

Dik, E. (2014). 6360 sayılı kanun bağlamında köylerin mahalleye çevrilmesi sorunu. Mülkiye Dergisi, 38(1), 75-102.

Erdagöz, Ö. (2012). Mahalle yönetimi ve geleceği. Uyuşmazlık Mahkemesi Dergisi, 0(1), 59-101.

Erdoğan, Ş. Ö. (2016). Mahalle ve Türkiye'de mahalle muhtarlığı. (Yüksek Lisans Tezi). Ankara Üniversitesi Sosyal Bilimler Enstitüsü, Ankara.

Erkan, N., Ç. (2019). Mahalle odaklı katılımın mekânsal boyutları. Mahalle odaklı katılım. (Ed. Özservet, Ç., Y. ve H. Küçük). Ankara: Astana Yayıncılık, 55-66.

Eryılmaz, B. ve Şen, M. L. (1994). 2000'li yıllara doğru Türkiye'de yerel yönetimler, sorunlar ve çözümler. MÜSİAD Araştırma Raporları: 5.

Genç, F. N. (2014). 6360 sayılı kanun ve Aydın'a etkileri. Adnan Menderes Üniversitesi Sosyal Bilimler Enstitüsü Dergisi, 1(5), $1-29$. 
Gezgüç, G. M., Aldemir, C. ve Uzun, T. (2016). 6360 sayılı kanun ve Muğla örneği. Kamu Yönetiminde Değişimin Yönü ve Etkileri (Kayfor 13 Bildiri Kitabı): 1664-1684. Konya.

Göküş. M. ve Alptürker, H. (2016). 6360 sayılı yasa ile köy yönetiminden mahalle yönetimine geçiş sonrası etkin hizmet sunumuna ilişkin muhtarların görüşü: Silifke köyleri örneği. Selçuk Üniversitesi Sosyal ve Teknik Araştırmalar Dergisi, 11, 67-86.

Gözler, K. (2013). 6360 sayılı kanun hakkında eleştiriler, Legal Hukuk Dergisi, 11(122), 37-82. (www.idare.gen.tr/6360-elestiriler.pdf). (20.12.2020).

Güler, B. A. (2009). Türkiye'nin yönetimi-yapı. Ankara: İmge Kitabevi Yayınları.

İzci, F. ve Turan, M. (2013). Türkiye'de büyükşehir belediyesi sistemi ve 6360 sayılı yasa ile büyükşehir belediyesi sisteminde meydana gelen değişimler: Van örneği. Süleyman Demirel Üniversitesi İktisadi ve İdari Bilimler Fakültesi Dergisi, 18(1), 117-152.

Kara, M. (2016). Türkiye'de merkezileşme-yerelleşme tartışmaları ve hizmet sunumunda ölçek sorunu. Yönetim Bilimleri Dergisi, 14(27), 249-276.

Karaarslan, M. (2013). Nasıl bir yerel yönetim? 6360 sayılı kanun bir değerlendirme. Dicle Üniversitesi Hukuk Fakültesi Dergisi, 1718(26-27-28-29), 123-162.

Kavruk, H. (2018). Mahalle, yerleşimi ve yönetimi. Ankara: Nobel Yayınevi.

Kaymal, C. (2017). Yerel özerklik ve yerel demokrasi açısından büyükşehir belediyesi reformu. Ulakbilge Sosyal Bilimler Dergisi, 5(13), 1137-1159.

Koç, M. (2018a). 6360 sayılı kanunun mahalleye dönüşen köylerde muhtarlı̆̆a etkisi (Muğla deneyimi). (Doktora Tezi). Marmara Üniversitesi Sosyal Bilimler Enstitüsü, İstanbul.

Koç, M. (2018b). Mahalle muhtarlarının yönetime katılımda yeni iletişim teknolojilerini kullanımı; Muğla ili üzerinden bir değerlendirme. Dijital Çă̆ın Etkisinde Yönetim - Siyaset - Kent. (Ed. Akman, E., N. Negiz, Ç. Akman ve H. M. Kiriş). Ankara: Detay Yayınc1lık, 89-102.

Ökmen, M., Çağatay, U., Uçar, A. ve Arslan, R. (2016). Köylerin mahalleye dönüşüm kararının etkilerini belirlemeye yönelik bir araştırma: Manisa büyükşsehir belediyesi örneği. Kamu Yönetiminde Değişimin Yönü ve Etkileri (Kayfor 13 Bildiri Kitabi): 1475-1487. Konya.

Ömürgönülşen, U., Öktem, M. K. ve Sadioğlu, U. (2018). Yeni büyükşehir belediye yasaları sonrasında Türkiye'de mahalle yönetimi araştırması (2013). Türkiye'de mahalle yönetimi araştırmaları. (Ed. K. U. Bilgin ve İ. Gündüzöz). Ankara : T.C. İçişleri Bakanlığı, (Klasmat Matbaacılık), 125-294.

Özçağlar, A. (2005). Türkiye'de mülki idare bölümlerinin idari coğrafya analizi. Coğrafi Bilimler Dergisi, 3(1), 1-25.

Özçağlar, A. (2009). Coğrafyaya giriş. Ankara: Ümit Ofset Matbaacılık. Özçağlar, A. (2015). Yönetsel coğrafya. Ankara: Nika Yayınevi.

Özçağlar, A. (2016). Büyükşehir belediyeli illerde kır ve kent nüfusunun tespiti mümkün mü?, TÜCAUM Uluslararası Coğrafya Sempozyuтu Bildiriler Kitabı: 271-291. Ankara.
Özer, M. A. (2013). Yerel yönetimler reformunda reform: 6360 sayıl1 Kanun'un düşündürdükleri. Yerel Politikalar Dergisi. 3, 97-126.

Palabıyı, H. ve Şermin, A. (2002). Türkiye'de mahalle yönetimi. Avrupa birliği ile bütünleşme sürecinde Türkiye'de yerel yönetimler. (Ed. B. Parlak ve H. Özgür). İstanbul: Alfa Basım Yayım Dağıtım, 331-371.

Safi, İ. ve Kurşuncu, T. (2019). Siyasal partizanlığın bir göstergesi olarak seçim hileleri ve Türkiye'deki bazı uygulamaları. Íktisadi İdari ve Siyasal Araştırmalar Dergisi, 4(8), 46-71.

Sağırekmekçi, A. (2015). Yerelleşme-merkezileşme tartışmaları bağlamında Türkiye'de mahalleye dönüşen köy yönetimlerinin mevcut durumu: Hatay örneği. (Yüksek Lisans Tezi). Mustafa Kemal Üniversitesi Sosyal Bilimler Enstitüsü, Hatay.

Sakar, S. E. (2019). Yeni büyükşehir yasasına kırsal kesimin bakış açısı: Adana örneği. (Yüksek Lisans Tezi). Çankırı Karatekin Üniversitesi Sosyal Bilimler Enstitüsü, Çankırı.

SBB (2020). On birinci kalkınma planı (2019-2023), https://www.sbb. gov.tr/wp-content/uploads/2020/04/YerelYonetimlerOzelIhtisas KomisyonuRaporu.pdf (24.12.2020).

Susta, G. O. (2018). 6360 sayıl yasa ile oluşan yeni büyükşsehir Yasası'nın kırsal alanda hizmet etkililiği açısından incelenmesi: İzmir ili Kiraz ilçesi araştırması. (Yüksek Lisans Tezi). Ankara Üniversitesi Fen Bilimleri Enstitüsü, Ankara.

Şahin, F. (2019). 6360 sayıl kanunla birlikte köy tüzel kişiliğinin kaldırlmasıly oluşan mahallelere verilen kamu hizmetlerinin değerlendirilmesi: Tekirdă̆ örneği. (Yükssek Lisans Tezi). Bartın Üniversitesi Sosyal Bilimler Enstitüsü, Bartın.

Şenol, E. (2019). Büyükşehir statüsündeki illerde kırsal nüfusun tespit: Ordu ili örneği. Türk Coğrafya Dergisi, 72, 53-63.

Taş, B. (2016). Türkiye’nin kırsal yerleşmeleri. İstanbul: Yeditepe Yayınevi.

Tekçe, Y. (2018). 6360 sayılı kanunun kapatılan köylere/yeni mahallelere etkisi: Aydın örneği. (Yüksek Lisans Tezi). Adnan Menderes Üniversitesi Sosyal Bilimler Enstitüsü, Aydın.

Türkan, O. (2020). Çankırı şehri sınırları ve yönetsel coğrafya bağlamında mahallelerin yeniden değerlendirilmesi. Çankırı şehir coğrafyast. (Ed. M. M. Kale ve O. Türkan). Ankara: Nobel Yayınc1lik, 99-133.

Ünal, F. ve Erol, V. (2019). 6360 sayılı kanun kapsamında köy ve mahalle yönetimlerinin yasal ve yapısal dönüşümü. Кати yönetiminde yapısal ve işlevsel dönüşüm (Kayfor 17 Bildiriler Kitabı): 86-99. Karaman.

Y1lmaz, V. ve Kaypak, Ş. (2017). 6360 sayılı yasa ile getirilen yeniliklerin yerel halk üzerindeki etkililiğinin ölçülmesi: Malatya büyükşehir belediyesi örneği. International Journal of Academic Value Studies, 3(15). 405-418.

Yüksel, C. (2016). Yerel yönetimlerde kaynak paylaşım sistemleri ve 6360 sayılı kanunla Türkiye'deki değişimler. Ankara Üniversitesi SBF Dergisi, 71(3), 731-756.

Zengin, O. (2014). Büyükşehir belediyesi sisteminin dönüşümü: son on y1lın değerlendirmesi. Ankara Barosu Dergisi, 2, 91-116. 


\section{İnternet Kaynakları}

https://www.e-icisleri.gov.tr/Anasayfa/MulkiIdariBolumleri.aspx

(12.12.2020).

https://atlas.harita.gov.tr/\#14.4/40.93388/33.48478 (12.12.2020).

https://sozluk.gov.tr (12.12.2020).

https://www.tbmm.gov.tr/sirasayi/donem24/yil01/ss338.pdf

(20.12.2020).

https://adres.nvi.gov.tr/VatandasIslemleri/AdresSorgu (12.12.2020).

https://atlas.harita.gov.tr/\#16.15/40.578572/32.790447 (12.12.2020).

https://data.tuik.gov.tr/Bulten/Index?p=Adrese-Dayali-Nufus-Kayit-

Sistemi-Sonuclari-2012-13425 (24.12.2020).

http://www.malkara.bel.tr/dosyalar/2015-8-muhtar-talepl_12642.pdf

(24.12.2020).
https://ekentrehberi.yenimahalle.bel.tr:81/KentrehberiApp/Index\# (26.12.2020).

https://ims.mamak.bel.tr/Projects/MAMAK/Pages/KRH.aspx (26.12.2020).

http://socbs.etimesgut.bel.tr:8080/EKentRehberi/ (26.12.2020).

https://biruni.tuik.gov.tr/medas/?locale=tr (12.12.2020).

https://cbs.kayseri.bel.tr/kayseri-ilce-mahalle-muhtar-bilgileri

(26.12.2020).

https://cbs.pendik.bel.tr/ (26.12.2020).

https://kentrehberi.izmir.bel.tr/izmirkentrehberi (26.12.2020).

https://cbs.cankaya.bel.tr/kentrehberi/ (26.12.2020).

https://gis.fatih.bel.tr/webgis/ (26.12.2020).

http://hbb.tkgm.gov.tr/home (26.12.2020). 